\title{
Structural and Spectroscopic Studies of Alkali-metal Exchanged Stilbites
}

\author{
Yanmei Ma ${ }^{\mathrm{a}, \mathrm{e}}$, Zhenxian Liu $^{\mathrm{b}}$, Aihui Geng ${ }^{\mathrm{c}}$, Thomas Vogt ${ }^{\mathrm{d}, \mathrm{f}}$ and Yongjae Lee ${ }^{\mathrm{a}, *}$
}

${ }^{a}$ Department of Earth System Sciences, Yonsei University, Seoul 03722, Korea

${ }^{\mathrm{b}}$ Geophysical Laboratory, Carnegie Institution of Washington, Washington, D.C. 20015, U.S.A.

${ }^{c}$ Changchun Institute of Optics, Fine Mechanics and Physics, Chinese Academy of Sciences, Changchun 130022, China

${ }^{\mathrm{d}}$ Department of Chemistry and Biochemistry \&NanoCenter, University of South Carolina, Columbia, SC 29208, U.S.A

${ }^{\mathrm{e}}$ College of Physics, Jilin University, Changchun 130012, China

${ }^{\mathrm{f}}$ Bragg Institute, Australian Science and Technology Organization, PMB 1, Menai, NSW 2234, Australia

Corresponding Author: Yongjae Lee, yongjaelee@yonsei.ac.kr

\begin{abstract}
The structural, infrared (IR) and Raman spectroscopic properties of alkalimetal exchanged $\left(\mathrm{Na}^{+}, \mathrm{K}^{+}, \mathrm{Rb}^{+}, \mathrm{Cs}^{+}\right)$zeolites with the stilbite (STI) framework have been studied by Rietveld analysis of high-resolution synchrotron X-ray powder diffraction data, micro-Raman and synchrotron IR spectroscopy at ambient conditions. Ordered arrangements of the extra-framework cations (EFCs) and $\mathrm{H}_{2} \mathrm{O}$ molecules were found at the intersection of the 10- and 8-ring channels as well as framework distortions and deformations of the channel system caused by the EFCs distributions. The T(5)-T(5) distances along the chains of the structural building units range from 8.921(1) to 8.979(5) $\AA$ and scale with the size of EFCs in Na-, K-, Rb-, Cs-STI. Furthermore, our spectroscopic studies show a systematic increase of characteristic band frequencies for the 4- and 5-ring breathing vibration modes in the far-IR spectral region with the size of the EFCs. The frequencies of the ring vibrational bands in the
\end{abstract}


IR and Raman spectra are very sensitive to the presence of specific EFCS, and framework distortion.

Keywords: Stilbite, alkali-metal exchange, synchrotron X-ray diffraction, synchrotron infrared spectroscopy, Raman spectroscopy. 


\section{INTRODUCTION}

Stilbite (type code STI, $\left.\left(\mathrm{NaCa}_{4}\right)\left[\mathrm{Al}_{9} \mathrm{Si}_{27} \mathrm{O}_{72}\right] \cdot 30 \mathrm{H}_{2} \mathrm{O}\right)$ is a natural zeolite belonging to the heulandite group and was discovered in 1756 by Cronstedt [1]. The crystal structure was initially determined by Galli and Gottardi in 1967 [2]. Subsequently, Slaughter et al. [3,4] refined the structure of the framework and located the cation and $\mathrm{H}_{2} \mathrm{O}$ positions. Stilbite has a monoclinic lattice, space group $\mathrm{C} 2 / \mathrm{m}$, with no $\mathrm{Si} / \mathrm{Al}$-ordering in the framework [3]. To better compare monoclinic stilbite with other related STI zeolites such as orthorhombic stellerite, $\mathrm{Ca}_{4}\left[\mathrm{Al}_{8} \mathrm{Si}_{28} \mathrm{O}_{72}\right] \cdot 28 \mathrm{H}_{2} \mathrm{O}$, and barrerite, $\mathrm{Na}_{8}\left[\mathrm{Al}_{8} \mathrm{Si}_{28} \mathrm{O}_{72}\right] \cdot 26 \mathrm{H}_{2} \mathrm{O}$, the structure of stilbite is often described in a pseudo-orthorhombic doubled unit cell with the non-standard space group F2/m [5]. STI zeolite frameworks are made up of differently connected chains of $4^{2} 5^{4}$ Secondary Building Units (SBUs) [6]. Two types of interconnected channels exist in the STI zeolite structure: a larger 10-membered ring channel along the [100] direction, and a smaller 8-membered ring channels along the [001] direction in orthorhombic structures.

Due to their unique structures, STI zeolites have three important properties: ion exchange, absorption and catalysis. Cation exchange is known to alter thermal stability, pore size and catalytic activity [7]. Furthermore, the defluoridation capacity of STI zeolites depends strongly on the cation present [8-10]. Dehydration studies of zeolites with the STI framework clearly show that the types and locations of cations impact the contraction and degradation of the framework [11]. The crystal structures of dehydrated $\mathrm{NH}_{4}-$ and $\mathrm{Na}, \mathrm{NH}_{4^{-}}$ exchanged stilbite reveal a slight distortion [12-13]. Dehydration results in new collapsed phases driven by the statistical breaking of T-O-T angle in the STI-type framework $[6,14]$.

Spectroscopic techniques are extensively used in characterizing zeolites by probing the phonon vibrations of their secondary building units (SBU) [15-16] and identifying other dynamical features within their frameworks [17-18]. Raman and IR spectroscopic techniques are able to probe chemical entities diffusing in and out of zeolites ${ }^{[19]}$ as well as to quickly confirm the presence of $\mathrm{H}_{2} \mathrm{O}$ molecules [16]. The correlation between the structure and the vibrational spectra in natural zeolites with different $\mathrm{SBUs}$ of $\mathrm{TO}_{4}$ tetrahedrons $(\mathrm{T}=\mathrm{Al}, \mathrm{Si})$ has been studied using Raman and IR methods [20]. A decade ago, Prasad et al. [21] monitored 
the dehydration and rehydration of natural stilbite using in situ Fourier transform infrared (FTIR) spectroscopy. The thermal dependence of the IR-active fundamental modes of $\mathrm{H}_{2} \mathrm{O}$ molecules was probed and the molecular linkages induced by dehydration were investigated by measuring the thermal variations of second order modes in the NIR spectra in the wavenumber region of $4000-8000 \mathrm{~cm}^{-1}$.

Recently, we have reported a series of alkali metal substituted natrolites (K-, Rb-, and Cs-natrolites) and carried out crystallographic and spectroscopic investigations [22-23]. Ionexchange leads to distinct changes in the IR and Raman spectra, and in the frequencies of the characteristic ring vibrations which depend on the size of the ring, the Al-to-Si ratio, the degree of deformation, degree of zeolite hydration, as well as EFCs present in the zeolite [20, 23]. However, there have not been any systematic studies of ion-exchanged stilbites using combined structural and spectroscopic techniques so far. Here we report for the first time the structural and spectroscopic investigation of $\mathrm{Na}^{+}, \mathrm{K}^{+}, \mathrm{Rb}^{+}$and $\mathrm{Cs}^{+}$-exchanged stilbites at ambient conditions.

\section{EXPERIMENTAL METHODS}

Alkali-metal cation-exchanged stilbites (M-STI, M = Na, K, Rb, Cs) were prepared using a fully saturated nitrate (ACS reagent grade from Sigma-Aldrich) solution and $0.2 \mathrm{~g}$ of ground natural stilbite in a 100:1 (solution volume vs. mineral weight) ratio. The solution was stirred at $80{ }^{\circ} \mathrm{C}$ in a sealed system to minimize the loss of water. After 24 hours, the solid was separated from the solution using a centrifuge. Each final product was washed via a vacuum filtration using a $200 \mathrm{ml}$ deionized water and subsequently air-dried. The dried powder was used for a second and third exchange step. Energy Dispersive Spectroscopy (EDS) confirmed a complete cation exchange. The vacuum filtration time of a few minutes is not long enough to allow for significant hydrolysis or back-exchange. Work by Ames shows that Cs exchange has quite slow kinetics, and we can neglect back-exchange of Cs during the short washing period [24]. In Ames' work the equilibrium time to exchange $\mathrm{Na}$ by Cs was 
found to be 64 hours. We are therefore sure that by exchanging for 72 hours we have completed Cs exchange.

High-resolution synchrotron X-ray powder diffraction data of Na-, K-, Rb-, and Cs-STI were collected at beamline 5A, the Pohang Accelerator Laboratory (PAL), Korea. The monochromatic beam with a wavelength of $0.6926(5) \AA$ was selected using a Si (111) double crystal and detuned by $30 \%$ to minimize contamination of higher harmonics, in particular, the third-order reflection of the silicon. An image plate detector (MAR345, Mar Research GmbH Co., Germany) in transmission mode was used to acquire the diffraction patterns. We used a $287 \mathrm{~mm}$ sample-to-detector distance ( $2 \theta$ coverage up to ca. $40^{\circ}$ ) and 10 seconds exposure time. Powdered alkali-metal cation-exchanged stilbite samples were packed into $0.5 \mathrm{~mm}$ quartz capillaries. The wavelength and 2-dimensional position of the incident beam, sample to detector distance and detector tilt were calibrated using $\mathrm{a} \mathrm{LaB}_{6}$ standard (SRM 660).

The structural refinements were performed by Rietveld methods using the GSAS suite of programs [25-26]. The background was fitted using a Chebyshev polynomial with 10 coefficients. The pseudo-Voigt profile function proposed by Thompson et al. [27] was used to fit the observed diffraction peaks. To reduce the number of parameters, isotropic displacement factors were refined by grouping them into (i) the framework tetrahedral atoms, (ii) the framework oxygen atoms and (iii) the extra-framework cations and (iv) $\mathrm{H}_{2} \mathrm{O}$ oxygen atoms. Geometrical restraints were applied for the $\mathrm{T}-\mathrm{O}(\mathrm{T}=\mathrm{Si}, \mathrm{Al})$ and $\mathrm{O}-\mathrm{O}$ bond distances of the tetrahedrons: the distances between $\mathrm{Si} / \mathrm{Al}-\mathrm{O}$ were restrained to target values of $1.649 \pm$ 0.001 , and the $\mathrm{O}-\mathrm{O}$ distances to $2.693 \pm 0.005 \AA$ for the $\mathrm{Si} / \mathrm{Al}$-tetrahedrons. $\mathrm{H}_{2} \mathrm{O}$ molecules were located along the elliptical channels using difference Fourier synthesis maps and modeled using only an oxygen scattering factor. In the final stages of the refinements, the weight of the restraints was reduced, which did not lead to any significant changes of the interatomic distances. The convergence was achieved by refining simultaneously all background and profile parameters, scale factor, lattice constants, $2 \theta$ zero, the atomic positional and thermal displacement parameters, as well as the occupancy factors for the extra-framework cations and $\mathrm{H}_{2} \mathrm{O} \mathrm{O}$ atoms. The final refined parameters are summarized in 
Table 1, and selected bond distances and angles are listed in Table 2.

Synchrotron IR spectra were obtained at U2A beamline of the National Synchrotron Light Source (NSLS-1) at Brookhaven National Laboratory (BNL). To avoid possible saturated absorption, pure sample powders were placed between two diamond anvils and compressed to a thin film before measurements. The far-IR spectra were collected using a Bruker IFS 66v/S FTIR spectrometer in combination with a custom-made vacuum microscope system equipped with a liquid helium cooled bolometer detector (Infrared Laboratories) and a $3.5 \mu \mathrm{m}$ thick Mylar beam splitter. More details on the optical layout of the beamline have been described elsewhere [28]. The mid-IR spectra were collected in transmission mode with a Bruker Vertex 80v FTIR spectrometer and a Hyperion 2000 IR microscope with a nitrogen-cooled MCT detector at the U2A side station. The spectra were

collected in the range of $100-700 \mathrm{~cm}^{-1}$ for the far-IR and $600-4500 \mathrm{~cm}^{-1}$ for the mid-IR. A spectral resolution of $4 \mathrm{~cm}^{-1}$ was applied to all IR measurements.

The Raman scattering measurements were recorded at room temperature using an Acton SpectraPro 500i spectrometer and a liquid nitrogen cooled CCD detector in a backscattering geometry. The $514.5 \mathrm{~nm}$ excitation light was generated using a frequency-doubled diode pumped Nd:Vanadyl laser (Coherent Company) [29]. The laser power on the sample was kept at $1.5 \mathrm{~mW}$. The average acquisition time for a single spectrum was 60 seconds.

\section{RESULTS AND DISCUSSIONS}

\subsection{Structure refinements}

The basic structural building unit of the stilbite framework is a $\mathrm{T}_{10} \mathrm{O}_{20}$ tetrahedral or 4-4=1 secondary building unit as defined by the International Zeolite Association [5] (Fig.1). These units are joined by sharing $\mathrm{T}(5)$ atoms along the $c$-axis to form chains, which are then linked laterally through T3-O9-T3 bridges to form dense silicate sheets running parallel to (010) (Fig.1). As a result, two kinds of interconnecting channels, 10-ring channels running parallel to the $a$-axis direction and smaller 8-ring channels along the [101] direction, are formed. Calcium and sodium cations as well as $\mathrm{H}_{2} \mathrm{O}$ molecules are distributed in the 
interpenetrated chains resulting in a composition of $\mathrm{Na}_{0.3} \mathrm{Ca}_{3.8} \mathrm{Al}_{7.3} \mathrm{Si}_{27} \mathrm{O}_{68.8}$ x $24.2 \mathrm{H}_{2} \mathrm{O}$ for natural stilbite (CaNa-STI in space group $\mathrm{C} 2 / \mathrm{m})$. Figure 2 shows its high-resolution synchrotron X-ray powder diffraction data. Diffraction peaks measured at ambient conditions can be indexed using a monoclinic unit cell with lattice constants of $a=13.609(1) \AA$, $\mathrm{b}=18.237(3) \AA, \mathrm{c}=11.237(2) \AA$, and $\beta=127.5(2)^{\circ}$, which is in good agreement with values reported in the literature [3]. Changes in the unit cell lengths and volume are depicted in Figure 3, which shows the ionic radius of extra-framework cation affects linearly the b-axis length and unit cell volume.

Using high-resolution synchrotron X-ray powder diffraction data, the refinements for $\mathrm{Na}-, \mathrm{K}-, \mathrm{Rb}-$, and Cs-STI were all done using the monoclinic space group $\mathrm{C} 2 / \mathrm{m}$ and initial model coordinates for the framework sites were taken from Slaughter et al. [3]. Structural details of the four compounds are listed in Tables 1 and 2. In our model for Na-STI two new extra-framework $\mathrm{Na}^{+}$sites were found in the cavities at the intersection of the 8-ring and 10ring channels. They are coordinated by three framework oxygen atoms and two $\mathrm{H}_{2} \mathrm{O}$ molecules with interatomic distances in the range of 3.09(7)-3.97(3) $\AA$ for $\mathrm{Na}(1)$ and 2.50(8)4.12(3) $\AA$ for $\mathrm{Na}$ (2) (Tables 1-2), respectively. In $\mathrm{K}_{8.0} \mathrm{Al}_{7.92} \mathrm{Si}_{28.08} \mathrm{O}_{72} 10 \mathrm{H}_{2} \mathrm{O}$, both potassium cation sites and two separate $\mathrm{H}_{2} \mathrm{O}$ sites are ordered and have full occupancies. The $\mathrm{K}^{+}$cations have larger distances to the framework oxygens, i.e., site (1) with $\mathrm{K}(1)-\mathrm{O}(8)$ distances of 3.09(1) $\AA$; site (2) with $\mathrm{K}(2)-\mathrm{O}(4)$ distances of 3.15(4) $\AA$ (Tables 1-2, Fig.4.). In the projection along the $a$-axis, the $\mathrm{Na}^{+}$and $\mathrm{K}^{+}$cations in Na-STI and K-STI are found near the center of the elliptical windows along the longer axis and the $\mathrm{H}_{2} \mathrm{O}$ molecules are fully occupied and located adjacent to the cations (Fig.4.). Another $\mathrm{H}_{2} \mathrm{O}$ molecule is found along the longer axis of the window connecting the $\mathrm{Na}^{+} / \mathrm{K}^{+}$cations. The refined content of $10 \mathrm{H}_{2} \mathrm{O}$ per unit cell in the Na-STI and K-STI is closed to what Luis found in Ca-NH4-STI at ambient conditions [8]. The chain rotation angle $\alpha$ of K-STI is significantly larger than in Na-STI, i.e.,8.05(1) $)^{\mathrm{o}}$ versus $1.78(3)^{\mathrm{o}}$, which in turn leads to a larger shift of the $\mathrm{O} 9$ atom and a chain bridging angle T3-O9-T3 of $159.5(8)^{\circ}$ in K-STI compared to $175.1(8)^{\circ}$ in Na-STI (Table 3).

The structural models for Rb-STI and Cs-STI are similar to those of Na-STI and K- 
STI. As observed in Na-STI and K-STI, the rubidium and cesium cations in STI are located at the intersection of the 10- and 8-ring channels with $\mathrm{H}_{2} \mathrm{O}$ molecules surrounding them. However, in contrast to Na-STI and K-STI, the cation sites in Rb-STI and Cs-STI are not fully occupied at ambient conditions, whereas the $\mathrm{H}_{2} \mathrm{O}$ sites are in both structures. The unitcell compositions are $\mathrm{Rb}_{7.98} \mathrm{Al}_{7.92} \mathrm{Si}_{28.08} \mathrm{O}_{72} \times 10 \mathrm{H}_{2} \mathrm{O}$ for $\mathrm{Rb}-\mathrm{STI}$ and $\mathrm{Cs}_{6.84} \mathrm{Al}_{7.92} \mathrm{Si}_{28.08} \mathrm{O}_{72} \mathrm{x}$ $10 \mathrm{H}_{2} \mathrm{O}$ for Cs-STI (Tables 1-2, Fig. 4.). The deficiency in the cesium occupancy might arise from partial disordering of the Cs sites. The framework distortion parameter $\alpha$ is $5.68(6)^{\circ}$ for $\mathrm{Rb}-\mathrm{STI}$ and $4.08(2)^{\circ}$ for Cs-STI (Table4). The distances between the fundamental secondary building units i.e., $\mathrm{T}(5)-\mathrm{T}(5), \mathrm{T}(4)-\mathrm{T}(4), \mathrm{T}(3)-\mathrm{T}(3)$, can also be used to characterize the framework distortion [13] and are listed in Table 3. We observe a gradual increase of the $\mathrm{T}(5)-\mathrm{T}(5)$ distance from $8.921(1)$ to $8.979(5) \AA$ with increasing extra-framework cation size in Na-, K-, Rb-, Cs- STI (Fig.5, Table4). This suggests that the secondary building unit of the stilbite framework becomes larger along the $c$-axis as the cation size increases. The rotation of the chains increases the $\mathrm{T}(5)-\mathrm{T}(5)-\mathrm{T}(5)$ angle, i.e. from $171.9(1)^{\circ}$ to $175.9(1)^{\circ}$ for K-STI and Cs-STI, respectively. The O9 atoms laterally bridge the SBUs units along [010]. In C2/m symmetry, the T3-O9-T3 bridge lies on the (010) mirror plane. In Na-STI, where the chain rotation angle $\alpha$ is $1.7(8)^{\circ}$, a shift of the $\mathrm{O} 9$ atom results in a chain bridging T3-O9-T3 angle of $175.1(8)^{\circ}$. We establish a linear relationship between the chain rotation angle $\alpha$ and the chain bridging angle T3-O9-T3 (Fig.6), i.e., the angle of the chain rotation shifts progressively to larger values as the T3-O9-T3 angle increases (Fig.6).

\subsection{Spectroscopic Characterization}

The synchrotron IR spectra of alkali-metal exchanged stilbites (M-STI, M = Na, K, $\mathrm{Rb}, \mathrm{Cs}$ ) at ambient conditions are shown in Figure 7. All observed peak positions in this study are listed in Table 4, and are in good agreement with the peak positions reported in the literatures for natural stilbite at ambient conditions [20,30]. The bands observed can be divided into two parts (Fig.7): (a) the far-IR spectra and (b) mid-IR spectra. In the 100-700 $\mathrm{cm}^{-1}$ far-IR range, the spectra contain the most characteristic vibrational modes of the rings, 
made of $\mathrm{SiO}_{4}$ and $\mathrm{AlO}_{4}$ tetrahedra. Among them are the absorption bands at $450 \mathrm{~cm}^{-1}$ assigned to the 5-membered ring breathing modes and at $554 \mathrm{~cm}^{-1}$ and $587 \mathrm{~cm}^{-1}$ to the 4membered rings breathing modes for natural-STI. The observed shoulder near $400 \mathrm{~cm}^{-1} \mathrm{can}$ be assigned to an optical lattice mode. This far-IR active mode gradually becomes more pronounced with an increase in the EFC radius (Fig.7a), which might be connected to the increase in the framework distortion. The most striking changes in the far-IR active modes are the systematic blue-shifts of the 4-ring breathing vibrational modes. The frequency increase is $\sim 20 \mathrm{~cm}^{-1}$ compared to natural stilbite (Table5). In K-STI, both 4- and 5- ring breathing vibrational modes have the largest blue-shift (Table1), which is concomitant with the largest distortion of the framework among the stilbites (M-STI, M = Na, K, Rb, Cs). This is consistent with our X-ray diffraction refinement results where K-STI has the largest chain rotation angle $\alpha$ of $8.05(1)^{\circ}$ and a chain bridging angle T3-O9-T3 of $159.5(8)^{\circ}$. These modes are also found to be sensitive to the changes in the chain rotation angle $\alpha$ and can therefore be used as a measure of the "channel opening" in the M-STI series (Fig.8). The Ca sites are closer to the center of the [100] channels and located on a (010) mirror plane, completely surrounded by $\mathrm{H}_{2} \mathrm{O}$ molecules. The $\mathrm{Na}$ sites are located on both sides of the mirror plane near the channel center $[4,14]$.

The characteristic bands of ring vibrations dominate the Raman spectra between 100 and $1300 \mathrm{~cm}^{-1}$ (Fig. 9). For natural stilbite, the strongest band at $410 \mathrm{~cm}^{-1}$ (and corresponding to the far-IR band at $450 \mathrm{~cm}^{-1}$ ) is assigned to 5-ring breathing modes, whereas the bands at $459 \mathrm{~cm}^{-1}$ and $496 \mathrm{~cm}^{-1}$ (corresponding to the far-IR band at 554 and $587 \mathrm{~cm}^{-1}$ ) originate from 4-membered ring breathing modes. Three Raman bands observed below 323 $\mathrm{cm}^{-1}$ are assigned to an optical lattice mode. The band at $621 \mathrm{~cm}^{-1}$ can be assigned to 8- or 10-membered ring vibrational modes [30]. The symmetric and anti-symmetric stretching vibrational modes of T-O correspond to the bands observed at $800 \mathrm{~cm}^{-1}$ and $1135 \mathrm{~cm}^{-1}$ [30] (Table5), respectively. In contrast to the IR spectrum, the Raman spectra reveal a slight redshift in the frequencies of the 5-ring breathing mode, whereas the bands from the 4-ring vibrational modes barely change when compared to natural stilbite. This means Raman 
spectra is affected little by exchanged-cations and demonstrates that infrared spectroscopy is a very sensitive tool to directly probe the cation locations in zeolites via their characteristic site vibrational modes [31], as well as the $\mathrm{O}-\mathrm{H}$ bending and stretching vibration modes of the $\mathrm{H}_{2} \mathrm{O}$ molecules [32].

The observed IR absorption bands from $\mathrm{H}_{2} \mathrm{O}$ molecules in the M-STI series $(\mathrm{M}=\mathrm{Na}$, $\mathrm{K}, \mathrm{Rb}, \mathrm{Cs}$ ) appear in the mid-IR spectra in the $600-4500 \mathrm{~cm}^{-1}$ range at ambient conditions (Fig.7b). The sharp band near $1640 \mathrm{~cm}^{-1}$ is due to the $\mathrm{H}-\mathrm{O}-\mathrm{H}$ bending vibration. In the $3200-$ $3600 \mathrm{~cm}^{-1}$ region we see strong $\mathrm{H}-\mathrm{O}-\mathrm{H}$ stretching modes, in particular three strong bands at $3257,3440,3566 \mathrm{~cm}^{-1}$. With the exception of in Na-STI, other mid-IR frequencies of the O$\mathrm{H}$ bending mode exhibit a slight red-shift when ion-exchanging natural-STI: $8 \mathrm{~cm}^{-1}$ in K-STI, $6 \mathrm{~cm}^{-1}$ in Rb-STI and $4 \mathrm{~cm}^{-1}$ in Cs-STI. We observe a gradual increase in the frequency of the $\mathrm{H}-\mathrm{O}-\mathrm{H}$ bending band from 1634 to $1642 \mathrm{~cm}^{-1}$ with increasing chain rotation angle $\alpha$ for the M-STI series ( $\mathrm{M}=\mathrm{Na}, \mathrm{Rb}, \mathrm{Cs}, \mathrm{K})$ (Fig.10). This red-shift of the $\mathrm{H}-\mathrm{O}-\mathrm{H}$ bending band is likely due to the change of the bonding of the $\mathrm{H}_{2} \mathrm{O}$ molecules within the channel. A similar effect is observed in exchanged natrolites [23].

\section{CONCLUSION}

In summary, we have systematically investigated the structural and spectroscopic properties of alkali-metal $\left(\mathrm{Na}^{+}, \mathrm{K}^{+}, \mathrm{Rb}^{+}, \mathrm{Cs}^{+}\right)$exchanged stilbites at ambient conditions using synchrotron X-ray diffraction, micro-Raman and synchrotron IR spectroscopic techniques. Our structural models show an ordered distribution of the extra-framework cations and water molecules at the intersection of 10- and 8-ring channels. The ion-exchange causes a framework distortion and deformation of the channel system. The frequency shift of the 4ring and 5-ring unit vibrations scales with the framework distortion. Striking variations in the observed vibrational spectra demonstrate that the ring vibrational modes in the IR spectra are very sensitive to the location of extra-framework cations.

\section{Acknowledgment}


This work was supported by the Global Research Laboratory (NRF-2009-00408) and National Research Laboratory (NRF-2015R1A2A1A01007227) Programs of the Korean Ministry of Science, ICT and Planning (MSIP). The use of the U2A beamline at the National Synchrotron Light Source beamline is supported by COMPRES, the Consortium for Materials Properties Research in Earth Sciences under NSF Cooperative Agreement EAR 0649658 and by the U.S. Department of Energy, Office of Science, Office of Basic Energy Sciences, under Contract No. DE-AC02-98CH10886. Y.M. thanks the support from the BK21Plus Instituteof Earth, Astronomy, and Atmospheric Sciences of Yonsei University, and the National Natural Science Foundation of China (Grant 11304114). T.V. thanks the Australian Nuclear Science and Technology Organization for support during an extended research visit.

\section{References:}

[1] A. Alberti, C. Vezzalini, In L. B. Sand and F. A. Mumpton, Eds., Natural Zeolites, Pergamon Press, New Jersey (1978) p.85-98.

[2] E. Galli, G. Gottardi, Mineral. Petrogr. Acta, 12 (1967) 1-10.

[3] M. Slaughter, Am. Mineral., 55 (1970) 387-397.

[4] S. Quartieri, G. Vezzalini, Zeolites, 7 (1987) 163-170.

[5] T. Armbruster, M. E. Gunter, Crystal Structures of Natural Zeolites, Reviews in Mineralogy and Geochemistry (2001) Vol. 45, 1529- 6466.

[6] R. Arletti, E. Mazzucato, G. Vezzalini, Am. Mineral., 91 (2006) 628-634.

[7] J. Li, J. Qiu, Y. Sun, Y. Long, Microporous and Mesoporous Mater., 37 (2000) 365-378.

[8] G. Luis, B. P. Ana, P. Joaquin, S. Taju, C. Yonas, D. Isabel, Microporous and Mesoporous Mater., 193 (2014) 93-102.

[9] M. S. Onyango, Y. Kojima, A. Kumar, D. Kuchar, M. Kubota, H. Matsuda, Sep. Sci. Technol., 41 (2006) 683-704.

[10] Z. Zhang, Y. Tan, M. Zhong, Desalination, 276 (2011) 246-252.

[11] E. Passaglia, Tschermaks Min. Petr. Mitt., 27 (1980) 67-78. 
[12] J. R. Pearce, W. J. Mortier, G. S. D. King, J. J. Pluth, I. M. Steele, J. V. Smith, In L. V. C. Rees, Ed., Proceedings of the "Fifth International Conference on Zeolites", Naples, Heyden, London. (1980) pp. 261.

[13] W. J. Mortier, Am. Mineral., 68 (1983) 414- 419.

[14] G. Cruciani, G. Artioli, A. Gualtieri, K. Stahl, and J. C. Hanson, Am. Mineral., 82 (1997) 729-739.

[15] W. M. Meier, Molecular Sieves, Society of Chemical Industry, London, (1968) 10.

[16] M. Lodzinski, R. Wrzalik, M. Sitarz, J. Mol. Struct. 744-747 (2005) 1017-1026.

[17] E. M. Flanigen, H. Khatami, and A. H. Szymanski, Advances in Chemistry, 101 (1971) 201-229.

[18] P. Makreski, G. Jovanovski, B. Kaitner, J. Mol. Struct., 924-926 (2009) 413-419.

[19] S.V. Goryainov, I. A. Belitsky, Phys. Chem. Mineral., 22 (1995) 443-452.

[20] W. Mozgawa, J. Mol. Struct., 596 (2001) 129-137.

[21] P. S. R. Prasad, K. S. Prasad, S. R. Murthy, Am. Mineral., 90 (2005) 1636-1640.

[22] Y. Lee, Y. Lee, D. Seoung, Am. Mineral., 95 (2010) 1636-1641.

[23] D. Liu, Z. Liu, Y. Lee, D. Seoung, Y. Lee, Am. Mineral., 97 (2012) 419-424.

[24] L. L. Ames, Can. Mineral., 8 (1966) 582-592.

[25] A. C. Larson, R. B. Von Dreele, GSAS; General Structure Analysis System, Report LAUR, Los Alamos National Laboratory, New Mexico. (1986) 86-748.

[26] B. H. Toby, EXPGUI, a graphical user interface for GSAS. J. Appl. Cryst., 34 (2001) $210-213$.

[27] P. Thompson, D. E. Cox, J. B. Hastings, J. Appl. Cryst., 20 (1987) 79-83.

[28] Z. Liu, J. Hu, H. K. Mao, R. J. Hemley, J. Phys.: Condens. Matter, 14 (2002) 1064110646.

[29] Q. Zhou, Y. Ma, Q. Cui, T. Cui, J. Zhang, Y. Xie, K. Yang, G. Zou, Rev. Sci. Instrum., 75 (2004) 2432-2434.

[30] P. Makreski, G. Jovanovski, B. Kaitner, J. Mol. Struct., 924-926 (2009) 413- 419.

[31] M. D. Baker, J. Godber, G. A. Ozin, J. Am. Chem. Soc., 107 (1985) 3033-3043. 
[32] B. A. Kolesov, C. A. Geiger, Am. Mineral., 91 (2006) 1039-1048. 


\section{Figure captions}

Fig.1. A polyhedral representation of the stilbite framework looking down the $a$-axis.

Fig. 2. Details of the changes in the synchrotron X-ray powder diffraction patterns measured for natural-STI, Na-STI, K-STI, Rb-STI, Cs-STI. Miller indices are shown for the first several Bragg peaks. Asterisks indicate impurity peaks. The wavelength was 0.6926(5) $\AA$.

Fig. 3. (a) Changes in the unit-cell edge lengths of Na-, K-, Rb-, and Cs-exchanged stilbite with the ionic radius at ambient conditions. (b) Changes in the unit-cell volume of the Na-, K-, $\mathrm{Rb}$-, and Cs-exchanged stilbite versus the ionic radius at ambient conditions. The structure model of natural stilbite was taken from the work of Slaughter et al.[3].

Fig. 4. Polyhedral representations of the structures of Na-, K-, Rb-, and Cs-exchanged stilbite viewed along $a$-axis showing the 10-membered ring channel. Large and hatched circles represent water $\mathrm{O}$ atoms; small colored ones represent extra-framework cations. Stripped tetrahedra illustrate a disordered distribution of $\mathrm{Si}$ and $\mathrm{Al}$ atoms in the framework.

Fig. 5. Dependency of the T(5)-T(5) distances on the extra-framework cation radius. The line is drawn only as a guide.

Fig. 6. Dependency of the T3-O9-T3 bridging angle on the chain rotation angle $\alpha$. The line is drawn only as a guide.

Fig. 7. (a) The far-IR spectra in the range of $100-700 \mathrm{~cm}^{-1}$ and (b) the mid-IR spectrain the range of $600-4500 \mathrm{~cm}^{-1}$ of the hydrated alkali-metal exchanged and natural stilbite at ambient conditions. The dotted curves in the right panel are the Lorentzian peak-fitting to the broad $\mathrm{O}-\mathrm{H}$ stretching vibrational bands.

Fig. 8. Frequency dependency of the 4-ring breathing mode on the chain rotation angle $\alpha$. The line is drawn only as a guide.

Fig. 9. Raman spectra of the hydrated alkali-metal exchanged stilbites at ambient conditions.

Fig. 10. Frequency dependency of the IR H-O-H bending mode on the chain rotation angle $\alpha$. The straight line is drawn only as a guide. 


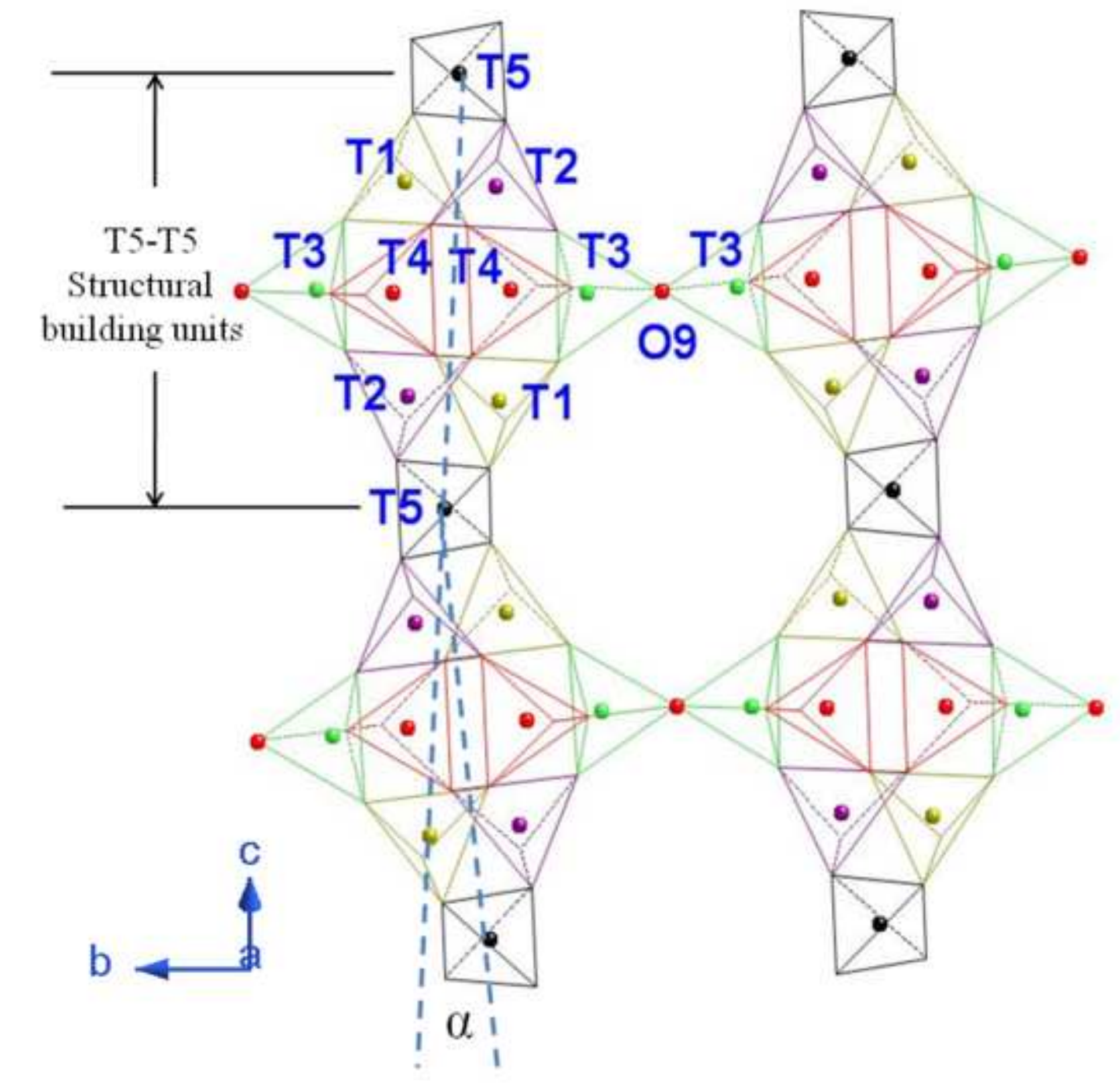

FIGURES 


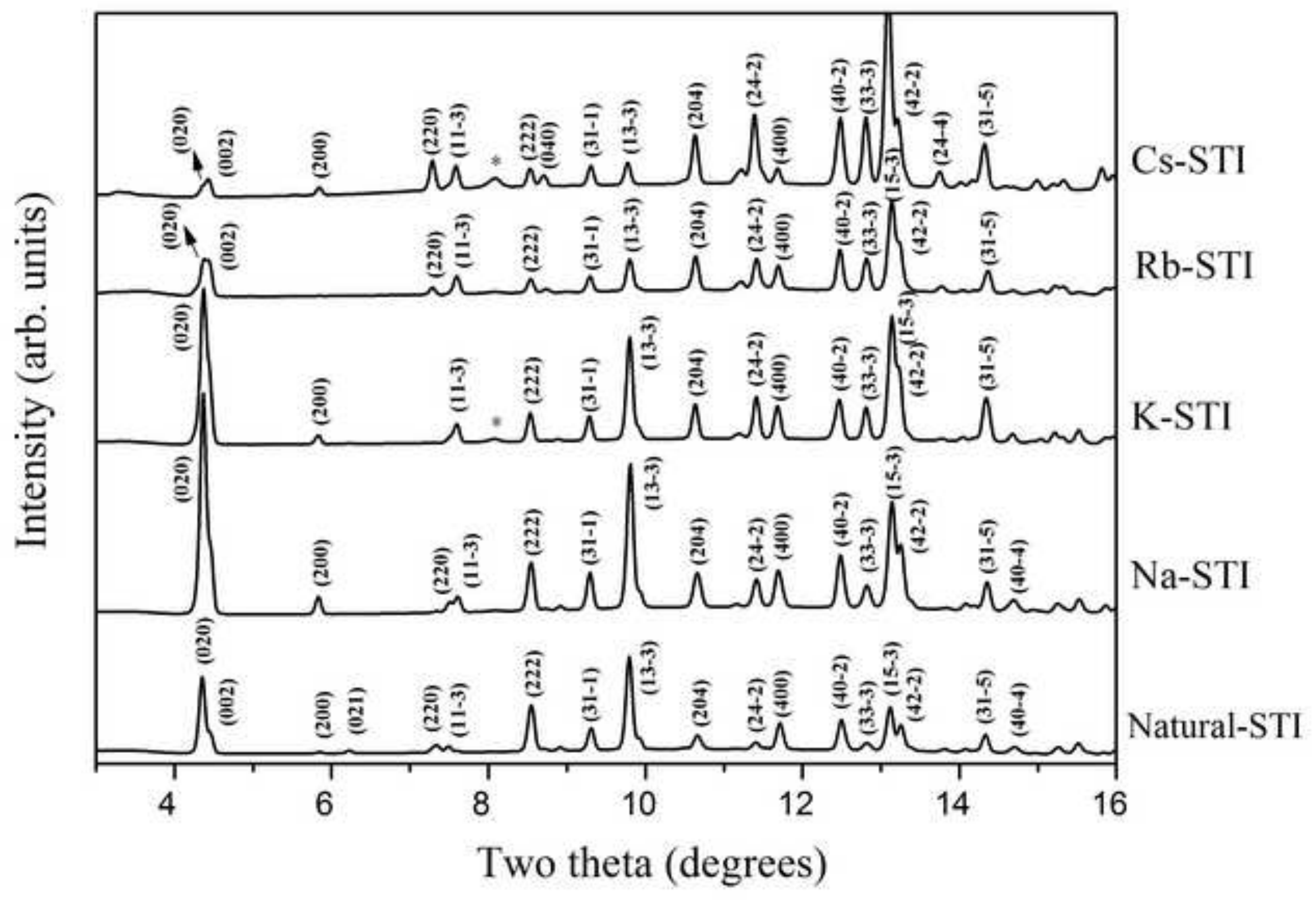


(a)

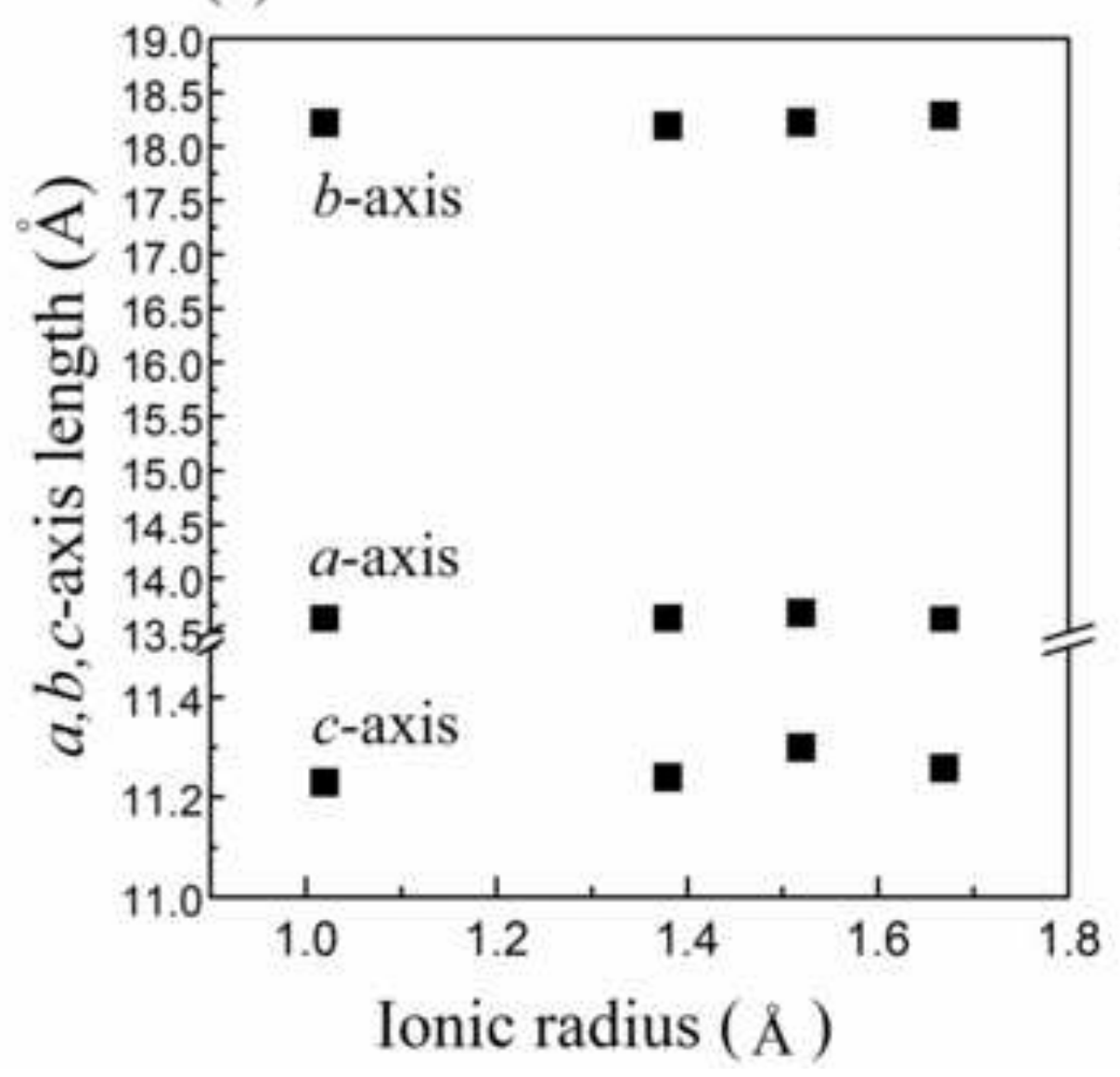

(b)

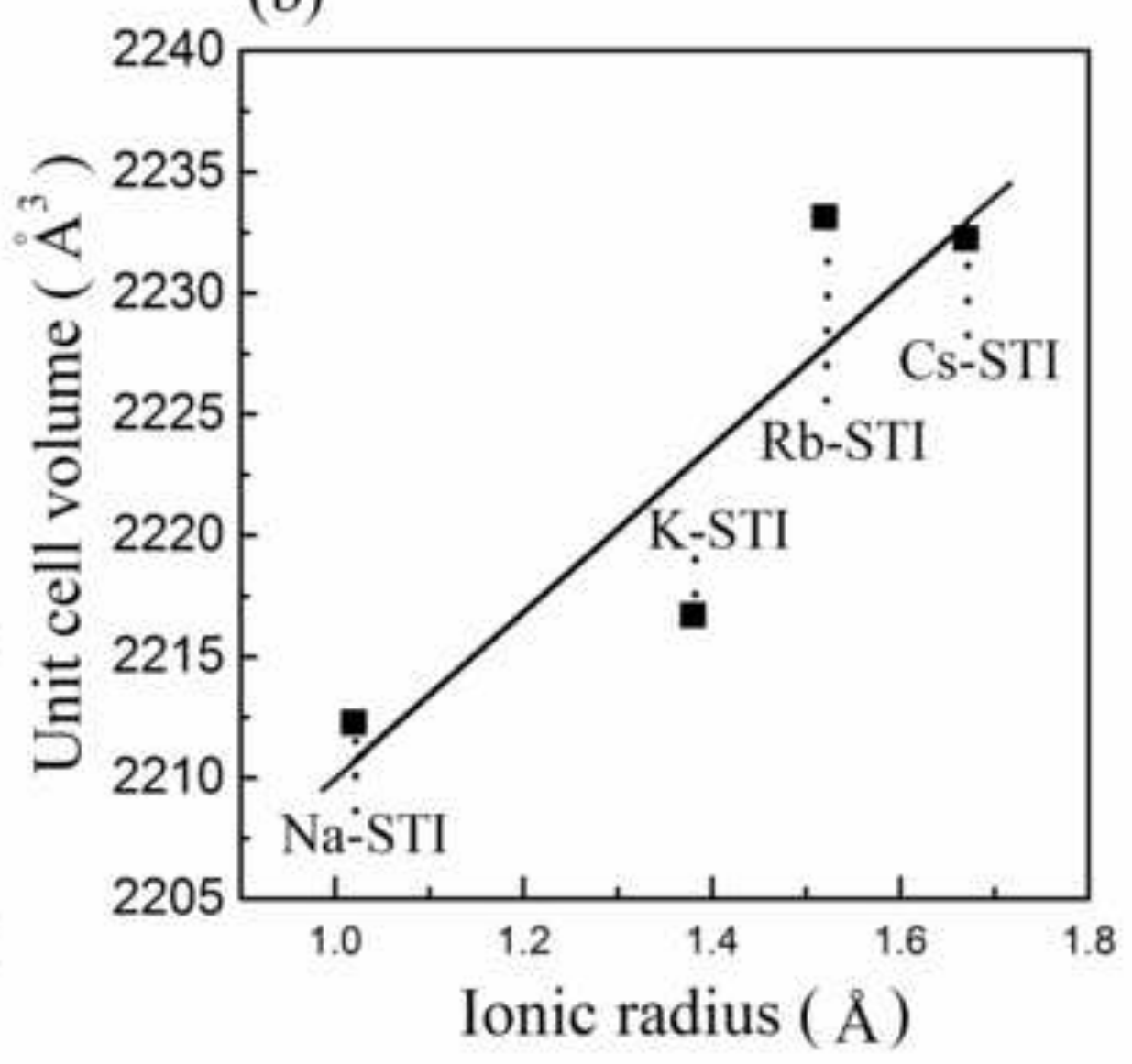


(a) Na-STI

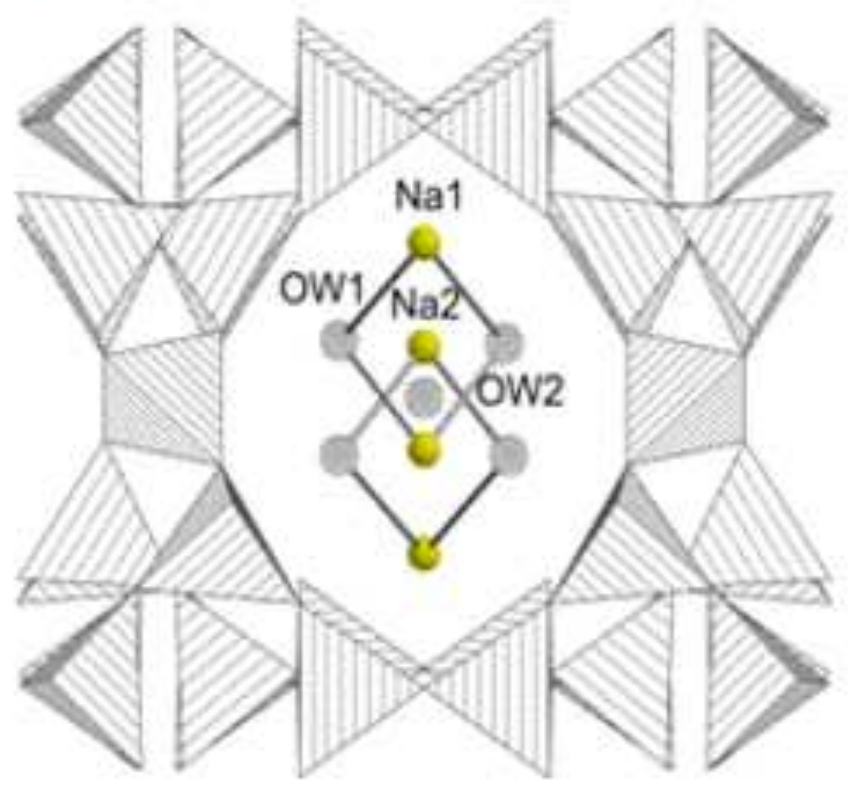

(c) Rb-STI

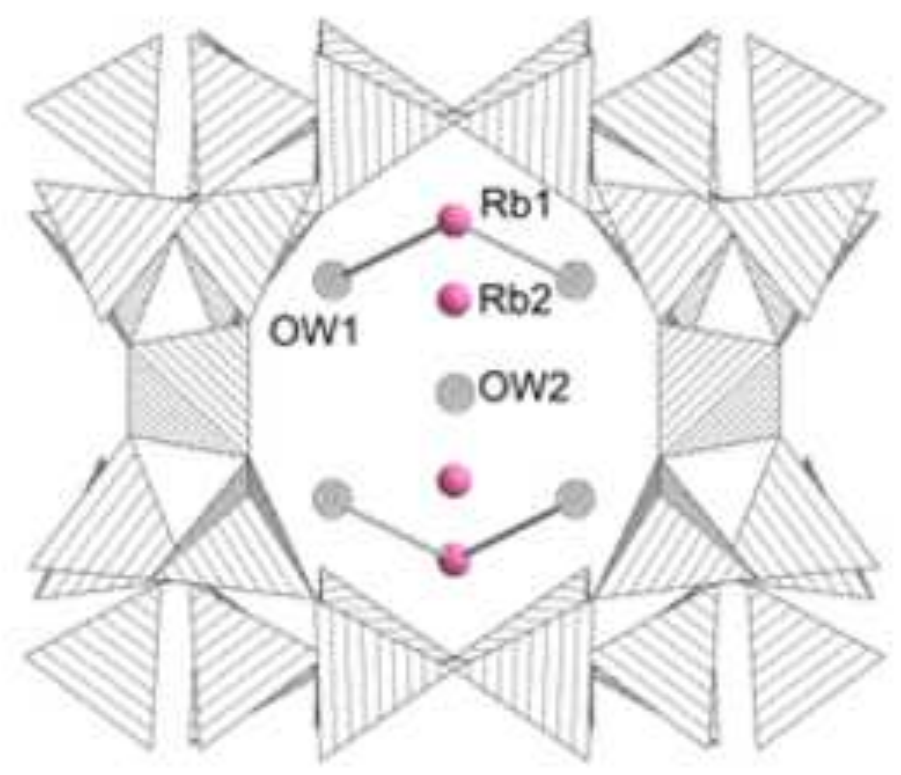

(b) K-STI

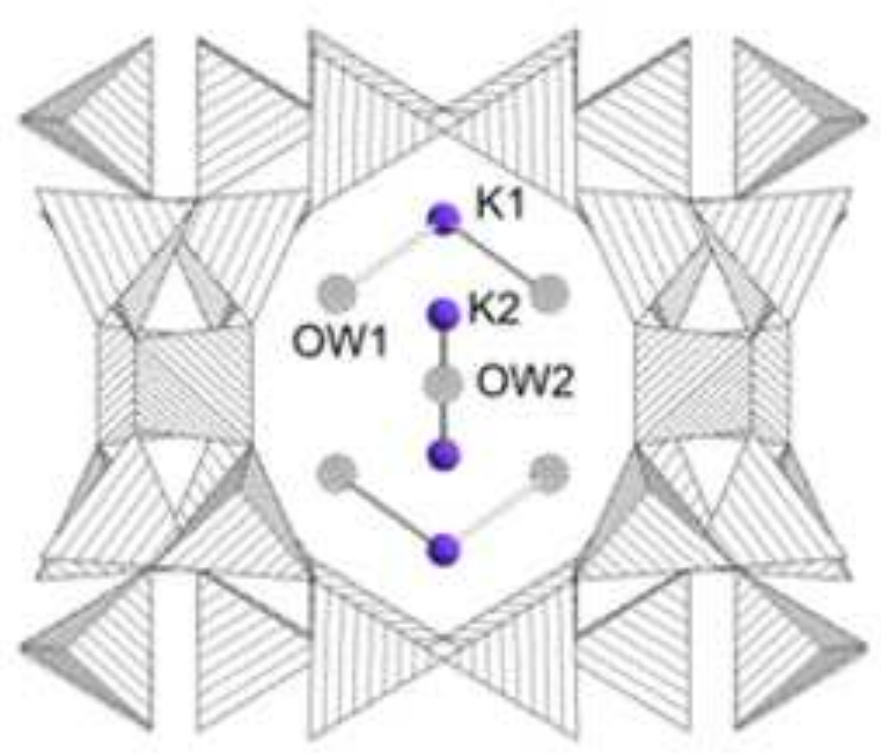

(d) $\mathrm{Cs}$-STI

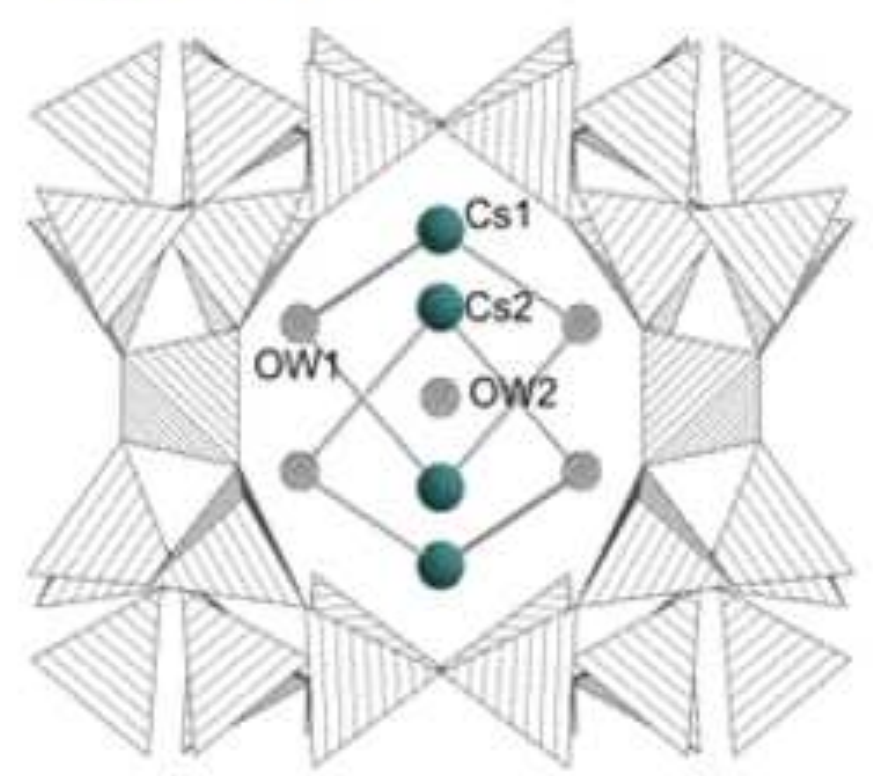




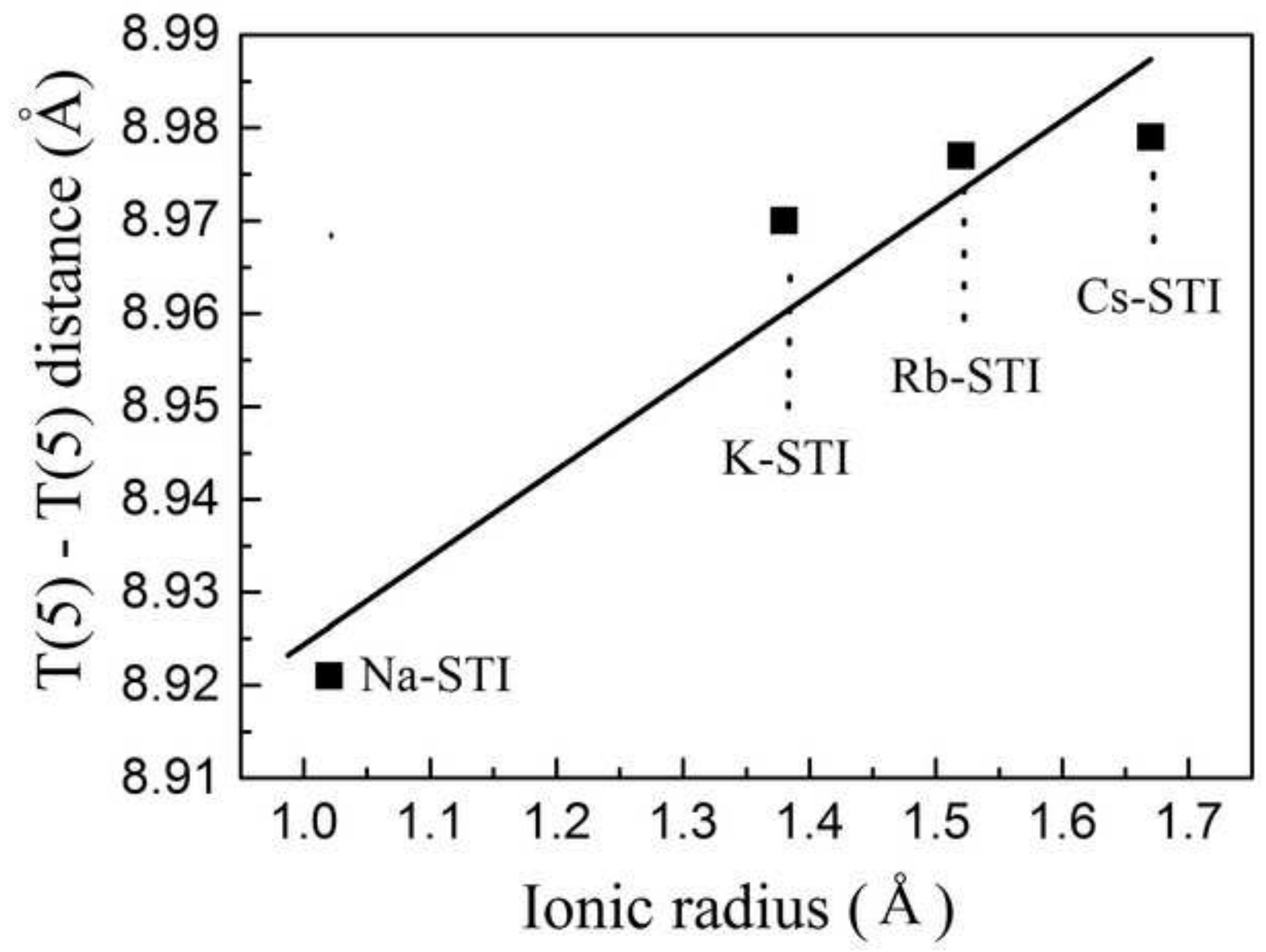




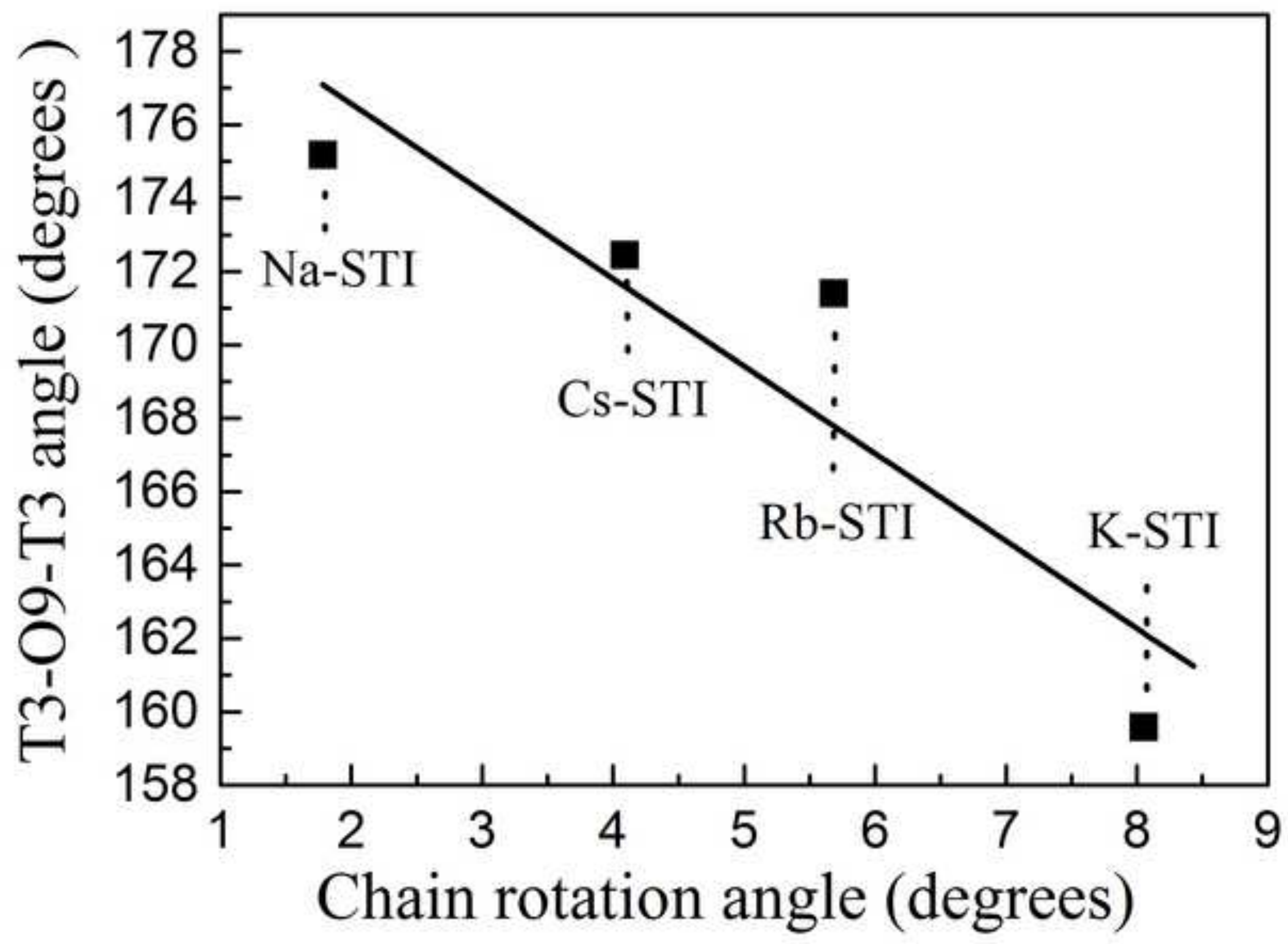




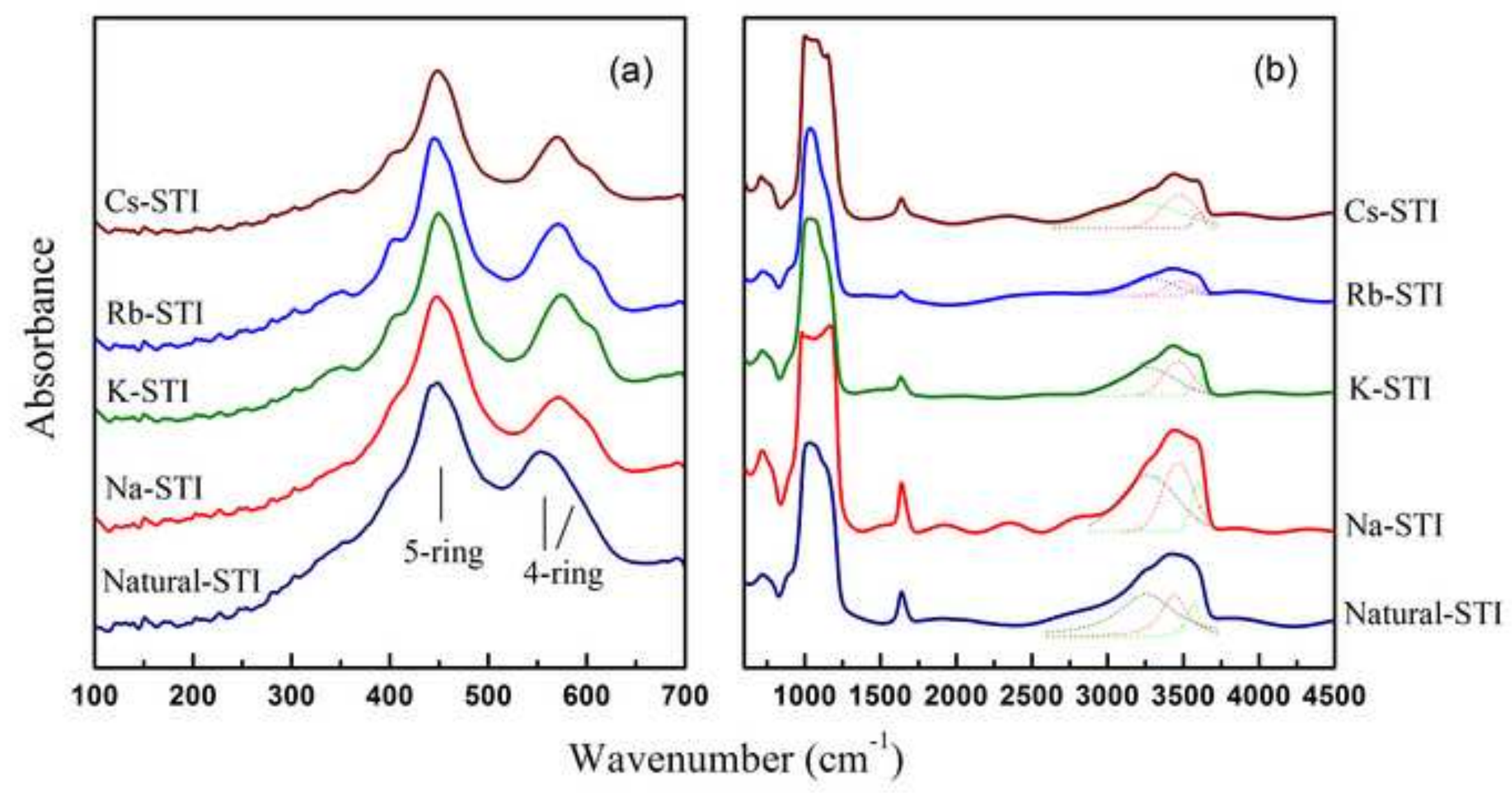




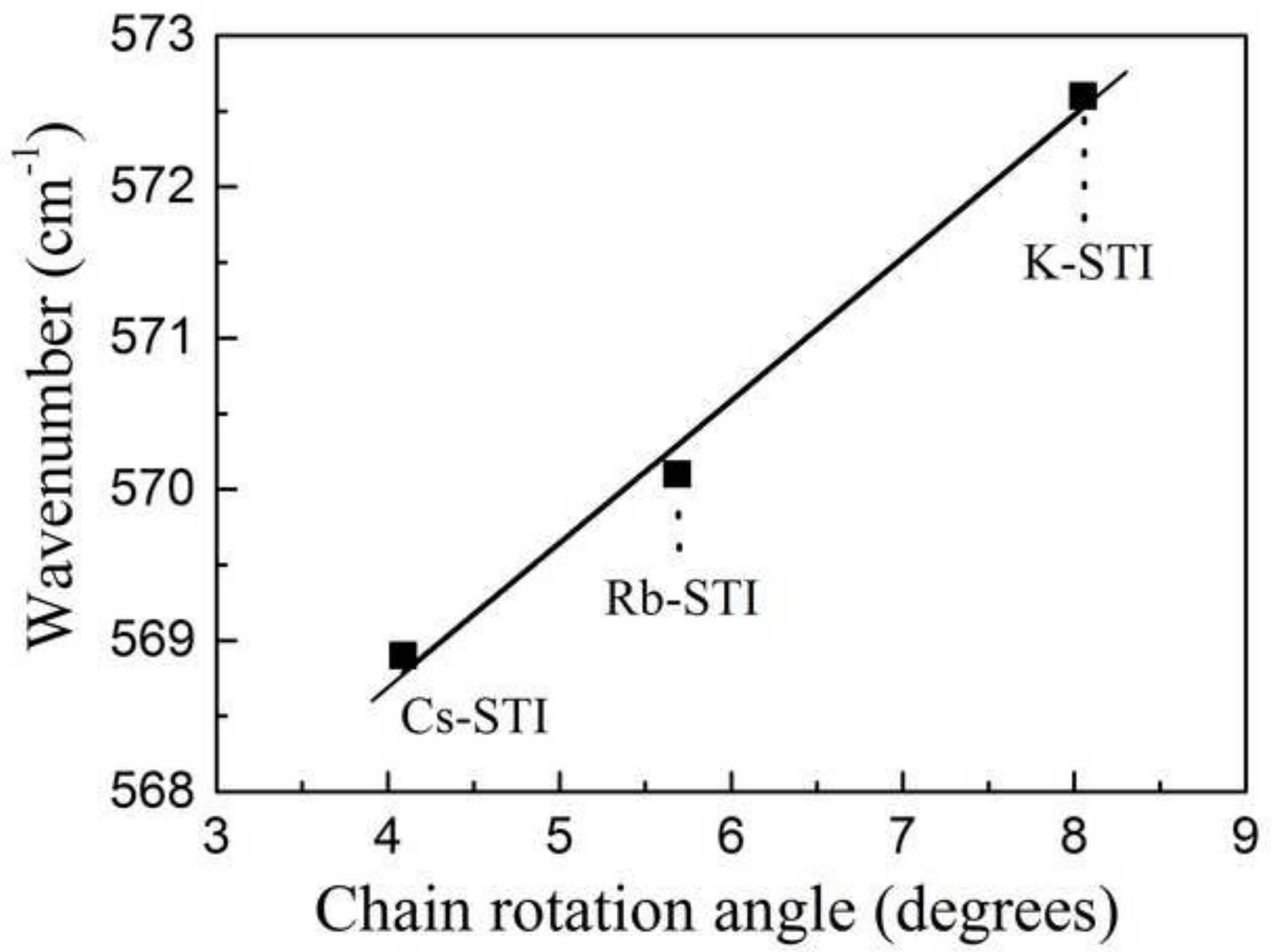




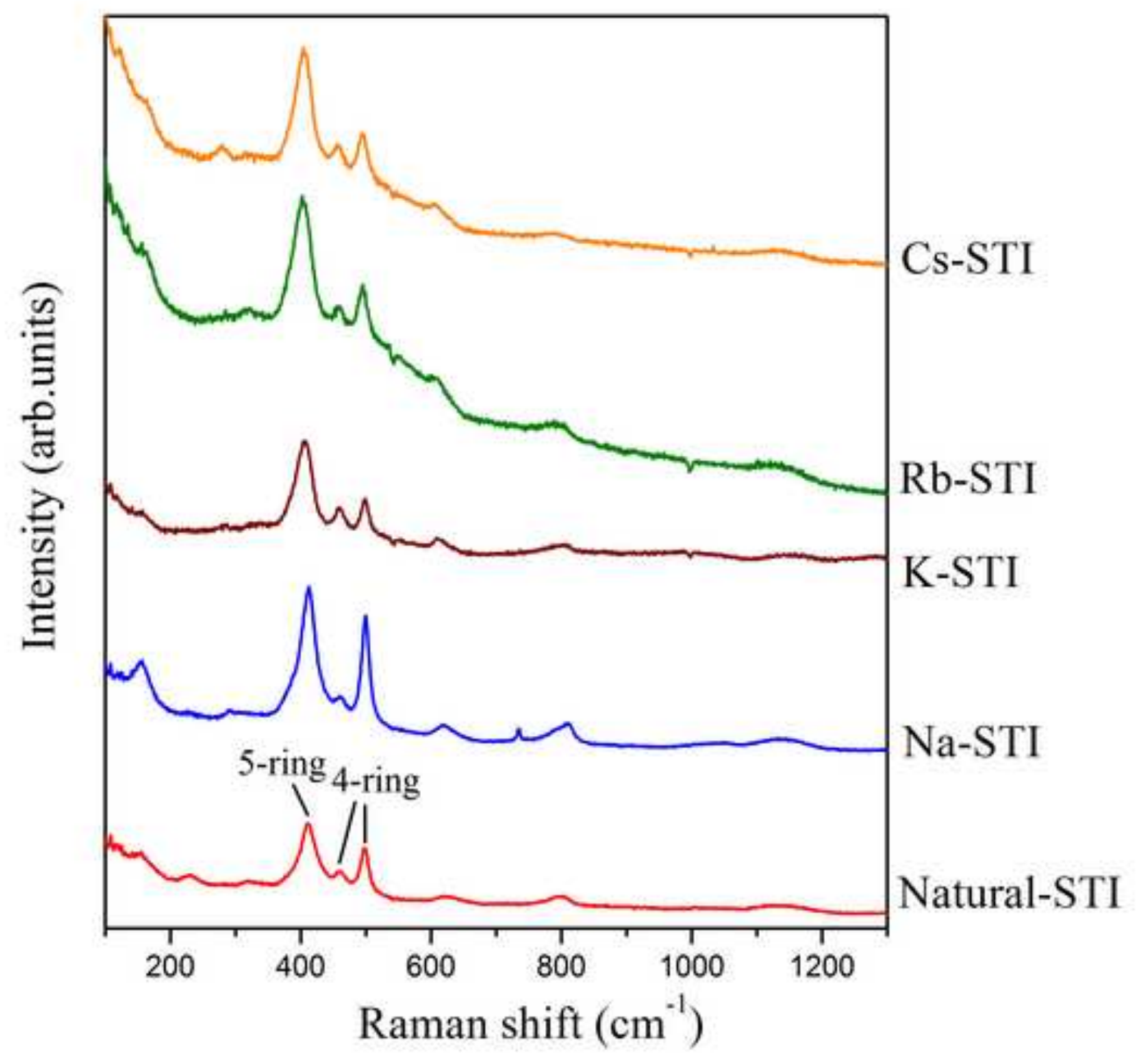




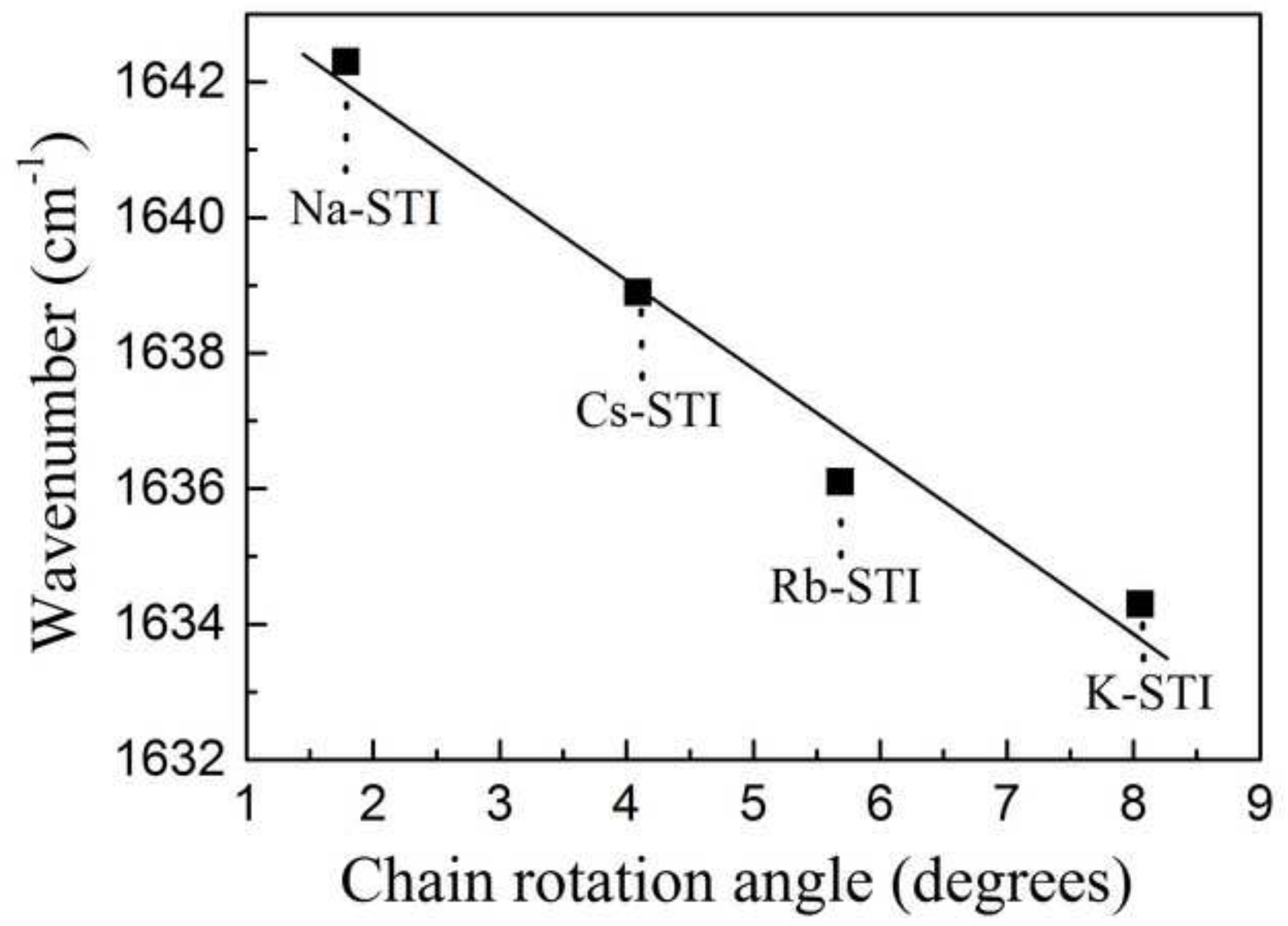


TABLE 1. Final refined atomic coordinates for $\mathrm{Na}-, \mathrm{K}-, \mathrm{Rb}-$, Cs-exchanged stilbites at ambient condition.

\begin{tabular}{|c|c|c|c|c|c|}
\hline & & $\mathrm{Na}-\mathrm{STI}$ & K-STI & Rb-STI & Cs-STI \\
\hline Space group & & $\mathrm{C} 2 / \mathrm{m}$ & $\mathrm{C} 2 / \mathrm{m}$ & $\mathrm{C} 2 / \mathrm{m}$ & $\mathrm{C} 2 / \mathrm{m}$ \\
\hline $\mathrm{R}_{\mathrm{wp}}(\%), \mathrm{X}^{2}$ & & $11.51,21.57$ & $15.41,25.65$ & $7.25,33.51$ & $21.39,37.74$ \\
\hline $\begin{array}{l}\text { Unit-cell } \\
\text { composition }\end{array}$ & & $\begin{array}{l}\mathrm{Na}_{8.0} \mathrm{Al}_{7.92} \mathrm{Si}_{28.08} \mathrm{O}_{72} \\
10 \mathrm{H}_{2} \mathrm{O}\end{array}$ & $\begin{array}{l}\mathrm{K}_{8.0} \mathrm{Al}_{7.92} \mathrm{Si}_{28.08} \mathrm{O}_{72} \\
10 \mathrm{H}_{2} \mathrm{O}\end{array}$ & $\begin{array}{l}\mathrm{Rb}_{7.98} \mathrm{Al}_{7.92} \mathrm{Si}_{28.08} \mathrm{O}_{72} 1 \\
\mathrm{OH}_{2} \mathrm{O}\end{array}$ & $\begin{array}{l}\mathrm{Cs}_{6.84} \mathrm{Al}_{7.92} \mathrm{Si}_{28.08} \mathrm{O}_{72} \mathrm{I} \\
\mathrm{OH}_{2} \mathrm{O}\end{array}$ \\
\hline \multirow{4}{*}{$\begin{array}{l}\text { Cell } \\
\text { lengths(Å) }\end{array}$} & $a$ & $13.616(3)$ & $13.622(22)$ & $13.672(1)$ & $13.607(5)$ \\
\hline & $b$ & $18.213(2)$ & $18.188(19)$ & $18.217(5)$ & $18.283(6)$ \\
\hline & $c$ & $11.229(3)$ & $11.238(18)$ & $11.299(7)$ & $11.257(5)$ \\
\hline & $\left.B 1^{\circ}\right)$ & $127.40(1)$ & $127.24(7)$ & $127.48(1)$ & $127.15(2)$ \\
\hline Cell volume & $V$ & $2212.3(7)$ & 2216.72(9) & 2233.1(5) & $2232.3(15)$ \\
\hline \multirow[t]{5}{*}{$T(1)$} & $x$ & $0.9775(1)$ & $0.9861(12)$ & $0.9792(1)$ & $0.9762(2)$ \\
\hline & $y$ & $0.1907(1)$ & $0.1993(12)$ & $0.1925(1)$ & $0.1894(2)$ \\
\hline & $z$ & $0.2368(1)$ & $0.2454(12)$ & $0.2385(1)$ & $0.2355(2)$ \\
\hline & Uiso & $0.0035(58)$ & $0.0041(52)$ & $0.0089(4)$ & $0.0004(2)$ \\
\hline & Occ. & $0.78,0.22$ & $0.78,0.22$ & $0.78,0.22$ & $0.78,0.22$ \\
\hline \multirow[t]{3}{*}{$T(2)$} & $x$ & $0.2647(1)$ & $0.2631(3)$ & $0.2635(3)$ & $0.2636(2)$ \\
\hline & $y$ & $0.3094(1)$ & $0.3079(3)$ & $0.3082(3)$ & $0.3083(2)$ \\
\hline & $z$ & $0.2611(1)$ & $0.2596(3)$ & $0.2599(3)$ & $0.2599(2)$ \\
\hline \multirow[t]{3}{*}{$T(3)$} & $x$ & $0.1907(1)$ & $0.1894(1)$ & $0.1904(5)$ & $0.1902(1)$ \\
\hline & $y$ & $0.0904(1)$ & $0.0891(1)$ & $0.0910(5)$ & $0.0899(1)$ \\
\hline & $z$ & $0.4856(1)$ & $0.4843(1)$ & $0.4853(5)$ & $0.4851(1)$ \\
\hline \multirow[t]{3}{*}{$T(4)$} & $x$ & $0.1068(1)$ & $0.1150(13)$ & $0.1102(2$ & $0.1075(2)$ \\
\hline & $y$ & $0.3125(1)$ & $0.3208(13)$ & $0.3160(2)$ & $0.3133(2)$ \\
\hline & $z$ & $0.4962(1)$ & $0.5044(13)$ & $0.4996(2)$ & $0.4969(2)$ \\
\hline \multirow[t]{3}{*}{$T(5)$} & $x$ & 0 & 0 & 0 & 0 \\
\hline & $y$ & $0.2538(1)$ & $0.2673(17)$ & $0.2622(2)$ & $0.2587(2)$ \\
\hline & $z$ & 0 & 0 & 0 & 0 \\
\hline \multirow[t]{5}{*}{$O(1)$} & $x$ & $0.9563(2)$ & $0.9649(9)$ & $0.9613(7)$ & $0.9576(3)$ \\
\hline & $y$ & $0.1987(2)$ & $0.2129(9)$ & $0.2084(1)$ & $0.2044(3)$ \\
\hline & $z$ & $0.0763(2)$ & $0.0865(6)$ & $0.0828(3)$ & $0.0786(3)$ \\
\hline & Uiso & $0.0024(19)$ & $0.0082(10)$ & $0.0150(8)$ & $0.0020(28)$ \\
\hline & Occ. & 1 & 1 & 1 & 1 \\
\hline \multirow[t]{4}{*}{$\mathrm{O}(2)$} & $x$ & $0.1156(2)$ & $0.1189(2)$ & $0.1149(5)$ & $0.1139(4)$ \\
\hline & $y$ & $0.3087(2)$ & $0.3213(8)$ & $0.3162(1)$ & $0.3123(3)$ \\
\hline & $z$ & $0.1203(6)$ & $0.1132(6)$ & $0.1236(5)$ & $0.1258(10)$ \\
\hline & Occ. & 1 & 1 & 1 & 1 \\
\hline \multirow[t]{4}{*}{$\mathrm{O}(3)$} & $x$ & $0.0382(10)$ & $0.0600(80)$ & $0.0482(3)$ & $0.0428(6)$ \\
\hline & $y$ & $0.2663(1)$ & $0.2721(18)$ & $0.2633(1)$ & $0.2601(3)$ \\
\hline & $z$ & $0.3378(2)$ & $0.3521(33)$ & $0.3515(9)$ & $0.3491(5)$ \\
\hline & Occ. & 1 & 1 & 1 & 1 \\
\hline \multirow[t]{4}{*}{$\mathrm{O}(4)$} & $x$ & $0.0639(3)$ & $0.0682(46)$ & $0.0672(5)$ & $0.0664(7)$ \\
\hline & $y$ & $0.1175(2)$ & $0.1246(19)$ & $0.1198(2)$ & $0.1180(3)$ \\
\hline & $z$ & $0.3235(5)$ & $0.3279(31)$ & $0.3237(1)$ & $0.3227(8)$ \\
\hline & Occ. & 1 & 1 & 1 & 1 \\
\hline \multirow[t]{4}{*}{$\mathrm{O}(5)$} & $x$ & $0.2948(9)$ & $0.2879(83)$ & $0.2911(4)$ & $0.2927(14)$ \\
\hline & $y$ & $0.2279(1)$ & $0.2284(17)$ & $0.2284(1)$ & $0.2284(3)$ \\
\hline & $z$ & $0.3404(3)$ & $0.3443(39)$ & $0.3432(3)$ & $0.3433(6)$ \\
\hline & Occ. & 1 & 1 & 1 & 1 \\
\hline \multirow[t]{2}{*}{$O(6)$} & $x$ & $0.2975(4)$ & $0.2973(43)$ & $0.3118(4)$ & $0.3136(6)$ \\
\hline & $y$ & $0.3826(2)$ & $0.3789(20)$ & $0.3755(4)$ & $0.3748(3)$ \\
\hline
\end{tabular}




\begin{tabular}{|c|c|c|c|c|c|}
\hline & $z$ & $0.3659(2)$ & $0.3692(26)$ & $0.3813(6)$ & $0.3828(4)$ \\
\hline & Occ. & 1 & 1 & 1 & 1 \\
\hline \multirow[t]{4}{*}{$O(7)$} & $x$ & $0.3360(1)$ & $0.3463(17)$ & $0.3391(2)$ & $0.3341(3)$ \\
\hline & $y$ & $0.3191(7)$ & $0.3096(14)$ & $0.3161(2)$ & $0.3172(14)$ \\
\hline & $z$ & $0.1848(2)$ & $0.1976(31)$ & $0.1896(7)$ & $0.1825(4)$ \\
\hline & Occ. & 1 & 1 & 1 & 1 \\
\hline \multirow[t]{4}{*}{$\mathrm{O}(8)$} & $x$ & $0.3164(1)$ & $0.3131(20)$ & $0.3189(3)$ & $0.3192(3)$ \\
\hline & $y$ & $0.1193(1)$ & $0.1061(21)$ & $0.1150(6)$ & $0.1208(3)$ \\
\hline & $z$ & $0.5095(4)$ & $0.4950(43)$ & $0.5137(6)$ & $0.5207(7)$ \\
\hline & Occ. & 1 & 1 & 1 & 1 \\
\hline \multirow[t]{4}{*}{$O(9)$} & $x$ & $0.1944(14)$ & $0.1659(94)$ & $0.1838(8)$ & $0.1919(29)$ \\
\hline & $y$ & 0 & 0 & 0 & 0 \\
\hline & $z$ & $0.4833(18)$ & $0.4798(71)$ & $0.4894(4)$ & $0.4958(31)$ \\
\hline & Occ. & 1 & 1 & 1 & 1 \\
\hline \multirow{4}{*}{$\mathrm{O}(10)$} & $x$ & 0 & 0 & 0 & 0 \\
\hline & $y$ & $0.3524(3)$ & $0.3530(39)$ & $0.3522(2)$ & $0.3523(5)$ \\
\hline & $z$ & 0.5 & 0.5 & 0.5 & 0.5 \\
\hline & Occ. & 1 & 1 & 1 & 1 \\
\hline \multirow[t]{5}{*}{ M1 } & $x$ & $0.349(4)$ & $0.467(18)$ & $0.362(8)$ & $0.356(3)$ \\
\hline & $y$ & 0 & 0 & 0 & 0 \\
\hline & $z$ & $0.277(4)$ & $0.313(19)$ & $0.310(8)$ & $0.307(2)$ \\
\hline & Uiso & $0.002(2)$ & $0.009(8)$ & $0.012(8)$ & $0.004(9)$ \\
\hline & Occ. & 1 & 1 & $0.99(7)$ & $0.82(7)$ \\
\hline \multirow[t]{4}{*}{$\mathrm{M} 2$} & $x$ & $0.749(4)$ & $0.876(14)$ & $0.781(3)$ & $0.815(4)$ \\
\hline & $y$ & 0 & 0 & 0 & 0 \\
\hline & $z$ & $0.092(4)$ & $0.135(21)$ & $0.166(3)$ & $0.165(4)$ \\
\hline & Occ. & 1 & 1 & $0.99(8)$ & $0.88(2)$ \\
\hline \multirow[t]{5}{*}{ OW1 } & $x$ & $0.427(3)$ & $0.229(29)$ & $0.458(1)$ & $0.345(14)$ \\
\hline & $y$ & $0.079(2)$ & $0.099(20)$ & $0.109(4)$ & $0.130(9)$ \\
\hline & $z$ & $0.102(4)$ & $0.170(30)$ & $0.200(7)$ & $0.135(13)$ \\
\hline & Uiso & $0.003(3)$ & $0.004(4)$ & $0.008(4)$ & $0.001(8)$ \\
\hline & Occ. & 1 & 1 & 1 & 1 \\
\hline \multirow[t]{4}{*}{ OW2 } & $x$ & 0 & 0 & 0 & 0 \\
\hline & $y$ & 0 & 0 & 0 & 0 \\
\hline & $z$ & 0 & 0 & 0 & 0 \\
\hline & Occ. & 1 & 1 & 1 & 1 \\
\hline
\end{tabular}


TABLE 2. Selected interatomic distances $(\AA)$ and angles $\left({ }^{\circ}\right)$ for Na-, K-, Rb-, Cs-exchanged stilbites at ambient condition.

\begin{tabular}{|c|c|c|c|c|}
\hline & $\mathrm{Na}-\mathrm{STI}$ & K-STI & $\mathrm{Rb}-\mathrm{STI}$ & Cs-STI \\
\hline $\mathrm{T}(1)-\mathrm{O}(1)$ & $1.648(8)$ & $1.645(8)$ & $1.648(3)$ & 1.649(1) \\
\hline $\mathrm{O}(3)$ & $1.650(4)$ & $1.655(1)$ & $1.648(5)$ & $1.650(9)$ \\
\hline $\mathrm{O}(4)$ & $1.648(5)$ & $1.644(9)$ & $1.648(2)$ & $1.649(5)$ \\
\hline$O(7)$ & $1.648(8)$ & $1.646(1)$ & $1.647(3)$ & $1.648(5)$ \\
\hline Mean & $1.649(1)$ & $1.647(9)$ & $1.648(1)$ & $1.649(5)$ \\
\hline $\mathrm{T}(2)-\mathrm{O}(2)$ & $1.649(5)$ & $1.647(5)$ & $1.647(3)$ & $1.648(6)$ \\
\hline$O(5)$ & $1.648(3)$ & $1.649(4)$ & $1.647(2)$ & $1.647(6)$ \\
\hline$O(6)$ & $1.648(8)$ & $1.648(1)$ & $1.647(2)$ & $1.649(2)$ \\
\hline$O(7)$ & $1.649(1)$ & $1.649(6)$ & $1.648(1)$ & $1.648(8)$ \\
\hline Mean & $1.648(9)$ & $1.648(6)$ & $1.647(6)$ & $1.648(6)$ \\
\hline $\mathrm{T}(3)-\mathrm{O}(4)$ & $1.649(7)$ & $1.649(2)$ & $1.649(5)$ & $1.650(3)$ \\
\hline $\mathrm{O}(6)$ & $1.650(2)$ & $1.648(5)$ & $1.648(3)$ & $1.650(3)$ \\
\hline $\mathrm{O}(8)$ & $1.648(6)$ & $1.645(2)$ & $1.645(6)$ & $1.647(3)$ \\
\hline $\mathrm{O}(9)$ & $1.648(6)$ & $1.647(4)$ & $1.647(1)$ & $1.647(3)$ \\
\hline Mean & $1.649(2)$ & $1.647(6)$ & $1.647(6)$ & $1.648(8)$ \\
\hline $\mathrm{T}(4)-\mathrm{O}(3)$ & $1.651(3)$ & $1.649(6)$ & $1.647(5)$ & $1.649(2)$ \\
\hline$O(5)$ & $1.649(3)$ & $1.648(8)$ & $1.646(9)$ & $1.647(1)$ \\
\hline $\mathrm{O}(8)$ & $1.649(6)$ & $1.647(7)$ & $1.648(4)$ & 1.649(1) \\
\hline $\mathrm{O}(10)$ & $1.648(8)$ & $1.645(1)$ & $1.647(4)$ & $1.646(8)$ \\
\hline Mean & $1.649(7)$ & $1.647(8)$ & $1.647(6)$ & $1.648(1)$ \\
\hline $\mathrm{T}(5)-\mathrm{O}(1) \times 2$ & $1.648(7)$ & $1.647(5)$ & $1.648(3)$ & $1.648(5)$ \\
\hline$O(2) \times 2$ & $1.649(3)$ & $1.648(1)$ & $1.648(2)$ & $1.648(7)$ \\
\hline Mean & $1.649(1)$ & $1.647(8)$ & $1.648(3)$ & $1.648(8)$ \\
\hline O1-T1-03 & $111.0(9)$ & $107.2(6)$ & 109.4(3) & 110.9(3) \\
\hline O1-T1-04 & $107.7(2)$ & $110.4(3)$ & $110.2(4)$ & $110.2(7)$ \\
\hline 01-T1-07 & $103.3(2)$ & 104.5(5) & $105.7(7)$ & $103.7(1)$ \\
\hline O3-T1-O4 & $112.8(8)$ & $110.2(5)$ & $107.8(5)$ & 107.1(9) \\
\hline O3-T1-07 & 108.0(1) & 113.1(5) & 109.5(5) & $108.3(2)$ \\
\hline O4-T1-07 & $112.5(1)$ & $110.9(7)$ & 113.9(5) & 116.4(1) \\
\hline O2-T2-05 & $105.5(7)$ & $114.2(7)$ & 109.5(4) & $107.5(4)$ \\
\hline O2-T2-06 & $109.4(2)$ & $104.8(1)$ & $110.7(6)$ & $113.0(6)$ \\
\hline O2-T2-07 & 105.8(5) & 106.5(3) & $108.6(5)$ & $107.6(1)$ \\
\hline O5-T2-06 & $118.0(6)$ & 112.9(1) & 110.1(9) & $109.8(8)$ \\
\hline O5-T2-07 & $110.2(1)$ & $107.9(6)$ & $110.0(5)$ & $111.8(5)$ \\
\hline O6-T2-07 & $107.0(8)$ & $110.1(6)$ & $106.6(4)$ & 106.9(3) \\
\hline O4-T3-06 & $114.8(4)$ & 110.1(3) & $108.2(4)$ & $108.0(2)$ \\
\hline 04-T3-08 & $111.7(8)$ & 109.0(1) & $112.0(4)$ & $112.8(2)$ \\
\hline 04-T3-09 & $107.6(3)$ & $107.5(4)$ & $108.7(4)$ & $110.6(1)$ \\
\hline 06-T3-08 & $106.6(7)$ & 111.8(9) & 109.1(2) & $104.8(2)$ \\
\hline 06-T3-09 & $109.1(7)$ & 106.1(8) & $108.7(7)$ & $109.3(1)$ \\
\hline 08-Т3-09 & $106.4(2)$ & 110.9(9) & $109.8(6)$ & $111.0(3)$ \\
\hline O3-T4-05 & $121.0(2)$ & $110.8(4)$ & $112.6(8)$ & $114.4(3)$ \\
\hline O3-T4-08 & 107.4(1) & 109.4(1) & $108.6(1)$ & $107.5(7)$ \\
\hline O3-T4-010 & $108.8(1)$ & $109.4(8)$ & $109.2(4)$ & $109.6(8)$ \\
\hline O5-T4-08 & 105.8(8) & 109.2(9) & 109.4(1) & 108.1(5) \\
\hline
\end{tabular}




\begin{tabular}{|c|c|c|c|c|}
\hline O5-T4-010 & $107.5(5)$ & $112.2(8)$ & $110.1(4)$ & $109.5(4)$ \\
\hline 08-T4-010 & $105.0(5)$ & $105.3(8)$ & $106.5(6)$ & $107.2(1)$ \\
\hline O1-T5-01 & $104.9(4)$ & $106.3(2)$ & $107.0(2)$ & $105.9(1)$ \\
\hline O1-T5-O2 & 114.1(9) & $113.7(5)$ & $110.0(7)$ & $110.4(5)$ \\
\hline O1-T5-02 & 109.1(9) & $108.2(4)$ & $111.4(9)$ & 111.4(9) \\
\hline O1-T5-02 & 109.1(9) & $108.2(4)$ & $111.4(9)$ & 111.4(9) \\
\hline O1-T5-02 & $114.1(9)$ & $113.7(5)$ & $110.0(7)$ & $110.4(5)$ \\
\hline O2-T5-O2 & $105.3(6)$ & $106.7(2)$ & $106.7(4)$ & 107.1(1) \\
\hline T1-01-T5 & $137.9(5)$ & $143.8(2)$ & $145.0(9)$ & $142.8(9)$ \\
\hline T2-O2-T5 & $142.7(8)$ & $134.6(6)$ & $137.5(5)$ & $139.5(4)$ \\
\hline T1-03-T4 & $152.2(3)$ & $151.0(7)$ & $160.2(5)$ & 162.1(3) \\
\hline T1-04-T3 & $141.8(6)$ & $145.5(2)$ & $143.1(3)$ & $143.1(8)$ \\
\hline T2-05-T4 & $140.4(6)$ & $145.8(3)$ & 143.3(9) & $142.0(9)$ \\
\hline T2-06-T3 & $141.1(7)$ & $146.4(7)$ & $145.2(6)$ & $145.2(6)$ \\
\hline T1-07-T2 & $137.2(5)$ & $144.5(7)$ & $140.5(5)$ & $137.0(3)$ \\
\hline T3-08-T4 & $148.6(2)$ & $136.9(8)$ & $144.0(4)$ & $148.6(3)$ \\
\hline T3-09-T3 & $175.1(8)$ & $159.5(8)$ & $171.4(1)$ & $172.4(5)$ \\
\hline T4-010-T4 & $127.7(2)$ & $138.3(3)$ & $132.8(1)$ & $128.6(8)$ \\
\hline $\mathrm{T}(1) \mathrm{O}(1)-\mathrm{O}(4)$ & $2.662(2)$ & $2.702(2)$ & $2.704(1)$ & $2.706(2)$ \\
\hline $\mathrm{O}(1)-\mathrm{O}(3)$ & $2.720(6)$ & $2.658(4)$ & $2.691(4)$ & $2.718(5)$ \\
\hline $\mathrm{O}(1)-\mathrm{O}(7)$ & $2.586(5)$ & $2.603(8)$ & $2.628(5)$ & $2.593(3)$ \\
\hline $\mathrm{O}(3)-\mathrm{O}(4)$ & $2.749(2)$ & $2.707(3)$ & $2.665(4)$ & $2.656(6)$ \\
\hline $\mathrm{O}(4)-\mathrm{O}(7)$ & $2.741(9)$ & $2.712(4)$ & $2.763(7)$ & $2.803(1)$ \\
\hline $\mathrm{O}(3)-\mathrm{O}(7)$ & $2.684(3)$ & $2.755(4)$ & $2.692(1)$ & $2.674(7)$ \\
\hline $\mathrm{T}(2) \mathrm{O}(2)-\mathrm{O}(5)$ & $2.626(4)$ & $2.769(2)$ & $2.691(5)$ & $2.658(7)$ \\
\hline $\mathrm{O}(2)-\mathrm{O}(6)$ & $2.693(2)$ & $2.611(4)$ & $2.712(4)$ & $2.750(4)$ \\
\hline $\mathrm{O}(2)-\mathrm{O}(7)$ & $2.631(3)$ & $2.642(5)$ & $2.677(4)$ & $2.660(6)$ \\
\hline $\mathrm{O}(5)-\mathrm{O}(7)$ & $2.704(1)$ & $2.668(3)$ & $2.716(1)$ & $2.730(6)$ \\
\hline $\mathrm{O}(6)-\mathrm{O}(7)$ & $2.653(1)$ & $2.703(1)$ & $2.643(1)$ & $2.650(1)$ \\
\hline $\mathrm{O}(5)-\mathrm{O}(6)$ & $2.828(4)$ & $2.748(2)$ & $2.702(4)$ & $2.698(8)$ \\
\hline $\mathrm{T}(3) \mathrm{O}(4)-\mathrm{O}(6)$ & $2.780(6)$ & $2.720(5)$ & $2.672(5)$ & $2.670(6)$ \\
\hline $\mathrm{O}(4)-\mathrm{O}(9)$ & $2.662(1)$ & $2.659(1)$ & $2.680(7)$ & $2.711(3)$ \\
\hline $\mathrm{O}(4)-\mathrm{O}(8)$ & $2.731(1)$ & $2.682(5)$ & $2.732(4)$ & $2.746(2)$ \\
\hline $\mathrm{O}(6)-\mathrm{O}(9)$ & $2.688(4)$ & $2.635(4)$ & $2.678(1)$ & $2.689(2)$ \\
\hline $\mathrm{O}(8)-\mathrm{O}(9)$ & $2.640(6)$ & $2.713(3)$ & $2.695(1)$ & $2.715(7)$ \\
\hline $\mathrm{O}(6)-\mathrm{O}(8)$ & $2.646(2)$ & $2.728(8)$ & $2.685(6)$ & $2.613(1)$ \\
\hline $\mathrm{T}(4) \mathrm{O}(3)-\mathrm{O}(8)$ & $2.660(4)$ & $2.691(2)$ & $2.676(5)$ & $2.661(3)$ \\
\hline $\mathrm{O}(3)-\mathrm{O}(10)$ & $2.683(6)$ & $2.690(2)$ & $2.687(4)$ & $2.694(6)$ \\
\hline $\mathrm{O}(3)-\mathrm{O}(5)$ & $2.873(1)$ & $2.716(5)$ & $2.742(4)$ & $2.771(2)$ \\
\hline $\mathrm{O}(5)-\mathrm{O}(8)$ & $2.632(7)$ & $2.688(5)$ & $2.689(5)$ & $2.669(3)$ \\
\hline $\mathrm{O}(5)-\mathrm{O}(10)$ & $2.660(8)$ & $2.735(4)$ & $2.701(7)$ & $2.690(8)$ \\
\hline $\mathrm{O}(8)-\mathrm{O}(10)$ & $2.617(6)$ & $2.619(4)$ & $2.641(2)$ & $2.652(9)$ \\
\hline $\mathrm{T}(5) \mathrm{O}(1)-\mathrm{O}(1)$ & $2.615(1)$ & $2.637(1)$ & $2.650(5)$ & $2.632(3)$ \\
\hline $\mathrm{O}(1)-\mathrm{O}(2)$ & $2.688(2)$ & $2.670(1)$ & $2.702(5)$ & $2.708(2)$ \\
\hline $\mathrm{O}(1)-\mathrm{O}(2)$ & $2.769(1)$ & $2.759(2)$ & $2.725(5)$ & $2.725(6)$ \\
\hline $\mathrm{O}(2)-\mathrm{O}(2)$ & $2.623(3)$ & $2.645(4)$ & $2.645(5)$ & $2.652(3)$ \\
\hline
\end{tabular}




\begin{tabular}{|c|c|c|c|c|}
\hline M1-M1 & $4.11(6)$ & $3.72(5)$ & $3.60(4)$ & $3.69(2)$ \\
\hline M1-M2 & $3.49(3)$ & $4.29(6)$ & $4.46(5)$ & $4.33(1)$ \\
\hline M1-08 & $3.63(1)$ & $3.09(1)$ & $3.42(3)$ & $3.51(7)$ \\
\hline M1-09 & $3.97(3)$ & $4.04(7)$ & $4.01(5)$ & $3.90(3)$ \\
\hline M1-010 & $3.38(5)$ & $3.25(8)$ & $3.23(7)$ & $3.27(1)$ \\
\hline $\mathrm{M} 2-\mathrm{O} 4$ & $4.01(9)$ & $3.15(4)$ & $3.84(1)$ & $3.49(3)$ \\
\hline M2-06 & $3.46(5)$ & $4.04(1)$ & $3.16(4)$ & $3.35(8)$ \\
\hline M2-07 & $3.44(1)$ & $3.60(3)$ & $3.41(5)$ & $3.34(7)$ \\
\hline OW1-M1 & $3.09(7) \times 2$ & $3.15(2) \times 2$ & $3.03(1) \times 2$ & $3.01(8) \times 2$ \\
\hline OW1-M2 & $2.50(8) \times 2$ & - & - & $3.59(5) \times 2$ \\
\hline OW1-01 & $4.08(1)$ & $3.22(6)$ & $3.59(1)$ & $3.55(5)$ \\
\hline OW1-O2 & $2.98(9)$ & $4.23(5)$ & $3.43(1)$ & $3.46(3)$ \\
\hline OW1-03 & $3.50(3)$ & $4.33(9)$ & $2.70(1)$ & $3.03(7)$ \\
\hline OW1-05 & $4.85(2)$ & $2.85(8)$ & $4.13(1)$ & $3.35(5)$ \\
\hline OW1-06 & $4.06(5)$ & $5.42(6)$ & $3.95(1)$ & $4.84(1)$ \\
\hline OW1-07 & $3.54(9)$ & $3.96(7)$ & $4.00(7)$ & $3.01(3)$ \\
\hline OW1-08 & $3.63(5)$ & $3.10(5)$ & $2.78(6)$ & $3.81(1)$ \\
\hline OW1-09 & $4.60(2)$ & $4.44(6)$ & $4.39(9)$ & - \\
\hline OW1-010 & $4.13(2)$ & $3.40(3)$ & $3.16(1)$ & $3.31(2)$ \\
\hline OW2-M1 & - & - & - & - \\
\hline OW2-M2 & - & $2.88(2)$ & - & - \\
\hline OW2-01 & $3.84(7)$ & $4.09(2)$ & $4.02(1)$ & $3.96(3)$ \\
\hline OW2-O4 & $3.83(3)$ & $3.92(2)$ & $3.85(3)$ & $3.83(5)$ \\
\hline OW2-09 & $4.35(1)$ & $4.40(4)$ & $4.47(1)$ & $4.51(3)$ \\
\hline ow1-ow1 & $2.90(8)$ & $3.58(6)$ & $3.98(2)$ & $4.76(6)$ \\
\hline oW2-OW1 & - & $3.06(8)$ & - & $4.63(1)$ \\
\hline
\end{tabular}


TABLE 3.Selected long range framework distances and angles for $\mathrm{Na}-$, K-, Rb-, Csexchanged stilbites at ambient conditions.

\begin{tabular}{|l|l|l|l|l|l|}
\hline & Na-STI & K-STI & Rb-STI & Cs-STI & d-Na-H-STI ${ }^{[13]}$ \\
\hline Length of the vectors $(\AA)$ & & & & & \\
\hline $\mathrm{T}(5)-\mathrm{T}(5)$ & $8.921(1)$ & $8.970(3)$ & $8.977(2)$ & $8.979(5)$ & 9.045 \\
\hline $\mathrm{T}(3)-\mathrm{T}(3)$ & $5.988(3)$ & $6.032(5)$ & $6.002(3)$ & $6.031(6)$ & 6.049 \\
\hline $\mathrm{T}(4)-\mathrm{T}(4)$ & $4.473(5)$ & $4.540(4)$ & $4.512(3)$ & $4.481(3)$ & 4.428 \\
\hline $\mathrm{T}(5)-\mathrm{T}(5)-\mathrm{T}(5)\left(^{\circ}\right)$ & $178.2(1)$ & $171.9(1)$ & $174.3(1)$ & $175.9(1)$ & - \\
\hline Rotation angle $\mathrm{a}\left(^{\circ}\right)$ & $1.783(1)$ & $8.051(2)$ & $5.686(2)$ & $4.089(2)$ & - \\
\hline
\end{tabular}


TABLE 4. The peak positions of all the observed IR vibrational modes of different alkalimetal exchanged stilbites at ambient condition.

\begin{tabular}{l|l|l|l|l|l|l}
\hline $\begin{array}{l}\text { Makreskiet.al. } \\
v\left(\mathrm{~cm}^{-1}\right)\end{array}$ & $\begin{array}{l}\text { Natural-STI } \\
v\left(\mathrm{~cm}^{-1}\right)\end{array}$ & $\begin{array}{l}\text { Na-STI } \\
v\left(\mathrm{~cm}^{-1}\right)\end{array}$ & $\begin{array}{l}\text { K-STI } \\
v\left(\mathrm{~cm}^{-1}\right)\end{array}$ & $\begin{array}{l}\text { Rb-STI } \\
v\left(\mathrm{~cm}^{-1}\right)\end{array}$ & $\begin{array}{l}\text { Cs-STI } \\
v\left(\mathrm{~cm}^{-1}\right)\end{array}$ & Assignment \\
\hline 117 & - & - & - & - & - & Lattice modes \\
\hline 159 & - & - & - & - & - & $v(\mathrm{Na}-\mathrm{O})$ \\
\hline 239 & - & - & - & - & - & Lattice modes \\
\hline 331 & 399.8 & 400.5 & 400.8 & 399.1 & 399.7 & Lattice modes \\
\hline 438 & 449.8 & 450.6 & 452.5 & 449.2 & 450.4 & 5-membered ring breathing vib. \\
\hline 464 & 554.2 & 570.3 & 572.6 & 570.1 & 568.9 & 4-membered ring breathing vib. \\
\hline 549 & 587.2 & 601.6 & 605.9 & 606.5 & 604.1 & 4-membered ring breathing vib. \\
\hline 674 & - & - & - & - & - & 8 - or 10- membered ring vib. \\
\hline 700 & 722.9 & 720.6 & 718.9 & 721.2 & 711.6 & $v_{\mathrm{s}}(\mathrm{Si}(\mathrm{Al})-\mathrm{O})$ \\
\hline 780 & 785.7 & 785.5 & 785.2 & 780.8 & 781.6 & $v_{\mathrm{s}}(\mathrm{Si}(\mathrm{Al})-\mathrm{O})$ \\
\hline 1030 & 1017.7 & 1026.3 & 1027.7 & 1026.1 & 1013.9 & $v_{\text {as }}(\mathrm{Si}(\mathrm{Al})-\mathrm{O})$ \\
\hline 1145 & 1157.4 & 1172.4 & 1151.9 & 1156.9 & 1140 & $v_{\text {as }}(\mathrm{Si}(\mathrm{Al})-\mathrm{O})$ \\
\hline 1649 & 1642 & 1642.3 & 1634.3 & 1636.1 & 1638.9 & $\delta\left(\mathrm{H}_{2} \mathrm{O}\right)$ \\
\hline 3255 & 3257.3 & 3268.9 & 3263.0 & 3302.6 & 3229.6 & $v\left(\mathrm{H}_{2} \mathrm{O}\right)$ \\
\hline 3420 & 3440.6 & 3466.2 & 3465.7 & 3474.9 & 3471.4 & $v\left(\mathrm{H}_{2} \mathrm{O}\right)$ \\
\hline 3610 & 3566.2 & 3595.3 & 3599.2 & 3592.1 & 3600.4 & $v\left(\mathrm{H}_{2} \mathrm{O}\right)$ \\
\hline
\end{tabular}


TABLE 5. The peak positions of all the observed Raman vibrational modes of different alkali-metal exchanged stilbites at ambient condition.

\begin{tabular}{l|l|l|l|l|l|l}
\hline $\begin{array}{c}\text { Makreski } \\
v\left(\mathrm{~cm}^{-1}\right)\end{array}$ & $\begin{array}{l}\text { Natural-STI } \\
v\left(\mathrm{~cm}^{-1}\right)\end{array}$ & $\begin{array}{l}\text { Na-STI } \\
v\left(\mathrm{~cm}^{-1}\right)\end{array}$ & $\begin{array}{l}\text { K-STI } \\
v\left(\mathrm{~cm}^{-1}\right)\end{array}$ & $\begin{array}{l}\text { Rb-STI } \\
v\left(\mathrm{~cm}^{-1}\right)\end{array}$ & $\begin{array}{l}\text { Cs-STI } \\
v\left(\mathrm{~cm}^{-1}\right)\end{array}$ & Assignment \\
\hline 121 & - & - & - & - & - & Lattice modes \\
\hline 152 & 154 & 151.9 & 152.9 & 152.1 & 152.5 & Lattice modes \\
\hline 234 & 227.8 & - & - & - & 277.8 & Lattice modes \\
\hline 311 & 323.1 & - & - & - & - & Lattice modes \\
\hline 409 & 411.2 & 411.1 & 404.5 & 401.4 & 403.5 & 5-membered ring breathing vib. \\
\hline 458 & 459.1 & 458.1 & 458.8 & 457.1 & 455.5 & 4-membered ring breathing vib. \\
\hline 496 & 497.5 & 498.9 & 497.8 & 494.3 & 494.1 & 4-membered ring breathing vib. \\
\hline 616 & 622.2 & 617.9 & 610.7 & 601.7 & 601.8 & 8- or 10- membered ring vib. \\
\hline 790 & 795.2 & 801.1 & 797.3 & 781.9 & 781.9 & v $(\mathrm{Si}(\mathrm{Al})-\mathrm{O})$ \\
\hline 1135 & 1130.8 & 1132.6 & - & - & 1122.3 & $v_{\text {as }}(\mathrm{Si}(\mathrm{Al})-\mathrm{O})$ \\
\hline
\end{tabular}




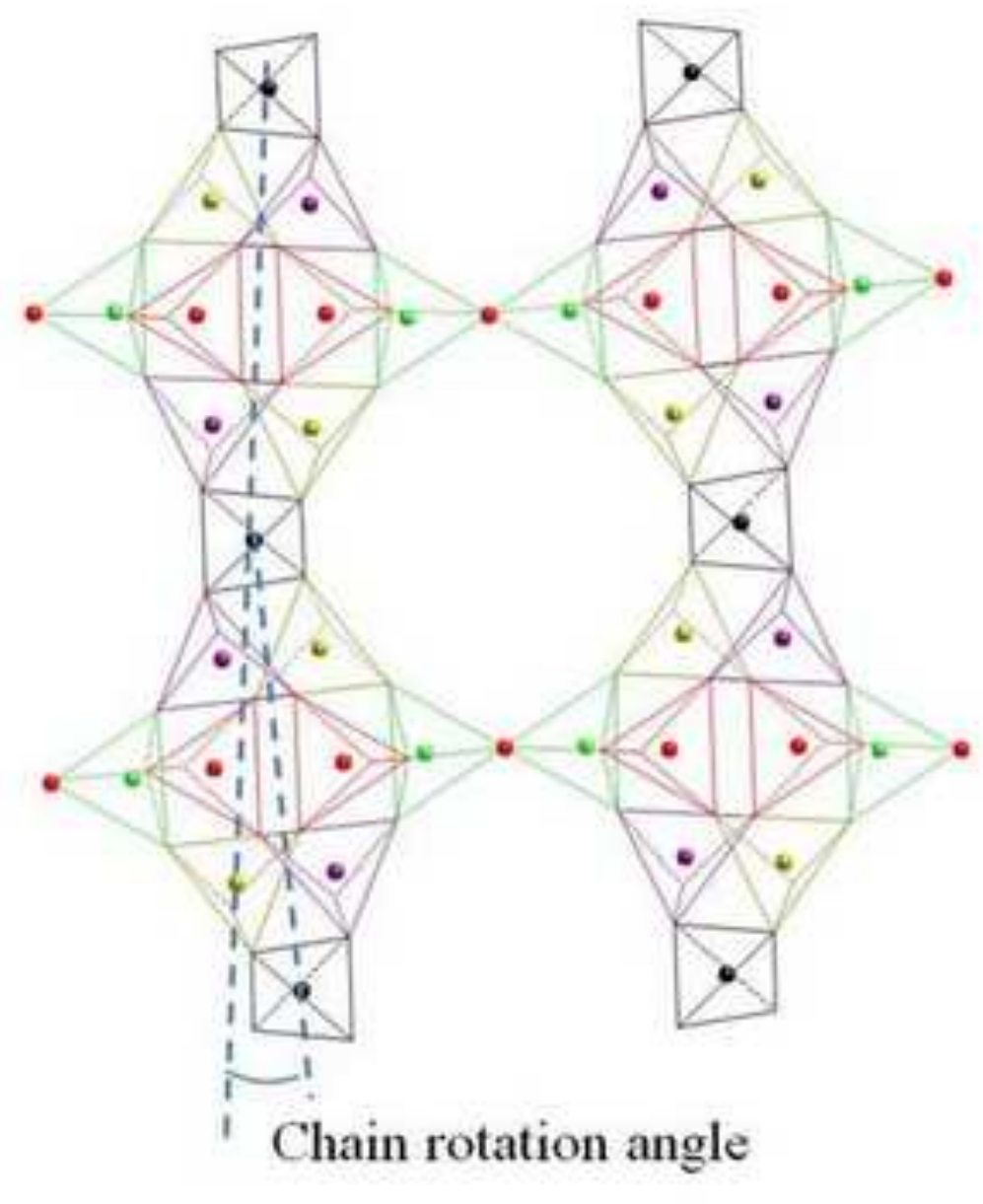

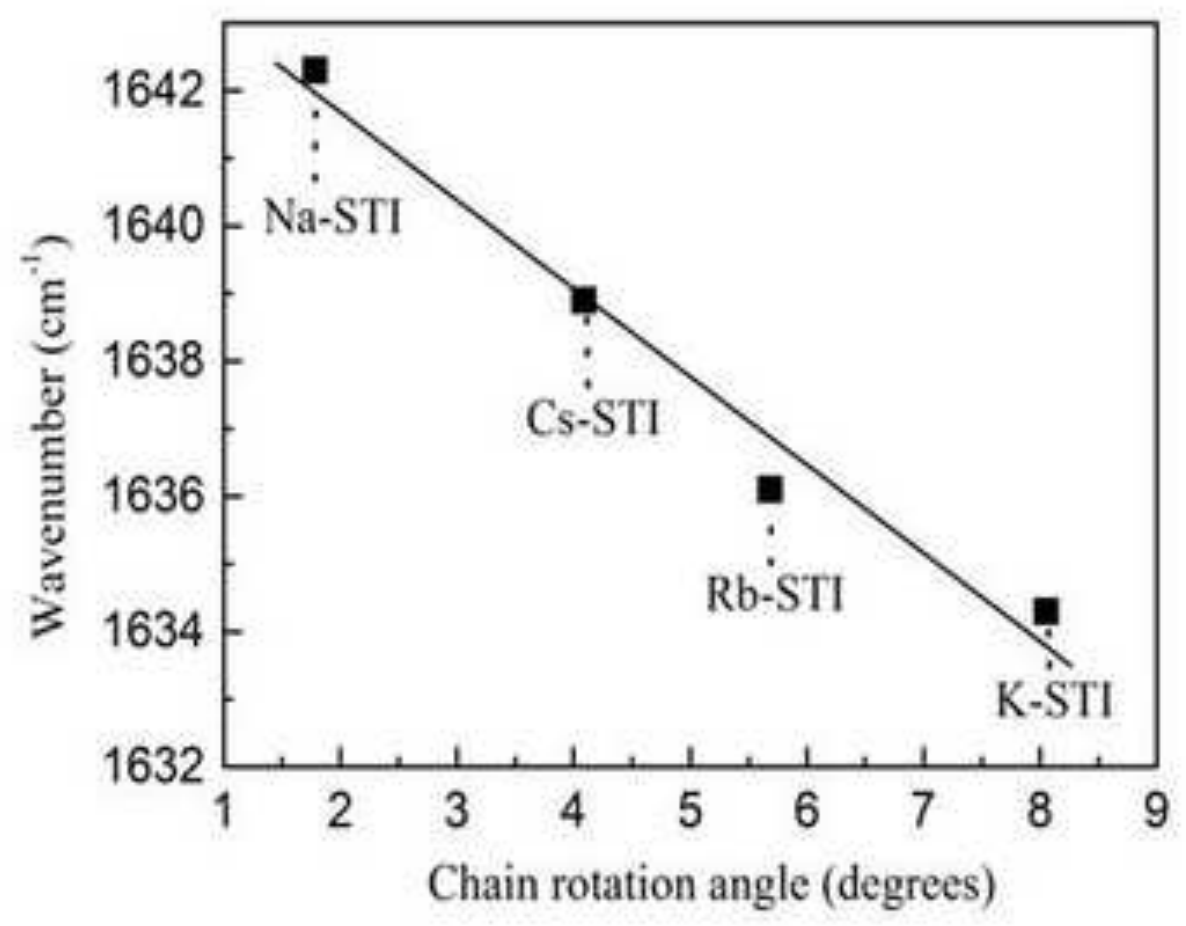

